\title{
Barriers to advance care planning with patients as perceived by nurses and other healthcare \\ professionals: A systematic review \\ Barriers to ACP: A systematic review
}

\begin{abstract}
Introduction

Advance care planning is a means for patients to communicate their wishes, fears and desires for future health decisions should they lose the ability to consider or communicate these. Despite being supported by governments and healthcare leaders, uptake amongst the general population remains low. Nurses play a crucial role in promoting and engaging with these discussions given their close relationship with patients and families in a range of clinical settings.
\end{abstract}

\section{Aim}

The aim of our review was to describe the barriers that nurses and healthcare professionals believe prevent them from exploring advance care planning with their patients.

\section{Method}

We carried out a systematic review of peer-reviewed journal articles from the databases MEDLINE, Embase, CINAHL Plus, Web of Science and Proquest Central), guided by the PRISMA checklist.

\section{Results}

Eleven articles were identified: all were self-reporting surveys using a mix of open and closed questions. They originated in the USA, Canada, Australia and 
Ireland. The participants were primarily nurses, but some focussed on other healthcare professionals.

The two most important barriers to advance care planning are lack of education and insufficient time. The concept appears to be well supported and nurses and healthcare professionals report themselves to be comfortable and confident to take on the responsibility.

\section{Conclusion}

There is a need for greater education and training for nurses and healthcare professionals. In particular, there needs to be better understanding of professional and legal responsibilities. The need for sufficient time to be made available to allow these conversations, in often busy settings, will need institutional and financial support.

\section{Relevance to Clinical Practice}

Increased training and knowledge are likely to lead to more positive attitudes and greater confidence for nurses, and other healthcare professionals, which should help support and encourage patient engagement with advance care planning.

\section{Impact Statement}

\section{What does this paper contribute to the wider global clinical community?}

- Advance care planning is a priority for healthcare systems around the world, seeking to preserve a patient's autonomy in times of incapacity and provide clinicians with insight into the wishes, preferences and values of patients.

- This review demonstrates that nurses and other healthcare professionals support the principles of advance care planning. 
- However, a lack of time and training is preventing it from becoming a part of routine practice.

\section{Key Words}

Advance care planning [MeSH]

Advance directives [MeSH]

Surveys and questionnaires [MeSH]

Health personnel [MeSH]

Nurses $[\mathrm{MeSH}]$ 


\section{Introduction}

Advance care planning is the practical application of a fundamental principle of law and medical ethics, that "a competent adult patient once properly informed has the unassailable legal right to refuse any or all medical treatment or care" (Re B (Adult: Refusal of Medical Treatment), 2002). The nature of critical illness is one that often results in a loss of capacity (Raymont et al., 2004) meaning patients are excluded from important decisions about their care unless their wishes have been discussed and/or documented in advance. The idea of an individual indicating in writing ahead of time the extent to which he/she would consent to treatment, a 'living will', was first proposed by the Euthanasia Society of America in 1967 (Sabatino, 2010). Subsequently, the idea of a "power of attorney' for healthcare, allowing a nominated individual to make decisions in case of incapacity, was mooted and these became incorporated into law and were widely adopted in the United States (Sabatino, 2010). The shortcomings of so-called 'living wills', particularly the narrow range of situations and decisions to which one document could apply, and the potential of abuse inherent in powers of attorney meant that by the 1990s 'advance directives' were recognised as an inadequate tool, if used alone, to ensure good decision making whilst caring for a terminally ill patient (Curd, 1999). A more global term of advance care planning was adopted with an emphasis on the broader process of communication as opposed to the completion of any particular form (Teno, Nelson, \& Lynn, 1994).

There is currently no standardised data on advance care planning discussions or advance directive completion rates making it difficult to understand their prevalence in the general population. Data that are available indicate that uptake can vary significantly by study with a systematic review of US studies finding the reported prevalence of advance directive completion ranging from 0 to 93.8\% (Yadav et al., 2017). This review concluded that approximately 1 in 3 US adults have completed some form of advance directive whilst data from 
Australia and Europe suggests completion rates of $~ 14 \%$ (White et al., 2014) and 4\% (De Vleminck et al., 2015; Royal College of Physicians, 2016) respectively. These relatively low levels are despite many countries having public health campaigns and charities designed to promote advance care planning (Austin Health, 2018; Dying Matters, 2018; The Conversation Project, 2018). This could be explained by a lack of appetite on behalf of the public, however surveys suggests high levels of support for the idea of discussing death and planning for end of life (NatCen Social Research, 2013). Another possibility, and one which this review will explore, is of difficulties which healthcare professionals experience when having, or attempting, advance care planning discussions with patients. Advance care planning happens in a range of settings including nursing and care homes, hospices, hospitals and within primary care. Nursing staff are frequently present and will often have the greatest 'face-to-face' contact with patients, and families, placing them in key positions to facilitate advance care planning (Newton, Clark, \& Ahlquist, 2009). Nursing regulatory bodies consider supporting patient self-determination and decision making a core proficiency of practice (American Nurses Association, 2015; Nursing \& Midwifery Council (NMC), 2018) and there is consensus that nurses should be playing a pivotal role in helping patients understand, explore and communicate their preferences regarding future medical treatments and end of life care (Briggs \& Colvin, 2002).

Cabana et al., (1999) utilised a framework of knowledge, attitudes and behaviour to map the barriers preventing physicians from adhering to clinical guidelines and we believe that this framework would also be suitable for mapping the barriers towards ACP. Knowledge, attitudes and practice (or behaviour) studies (KAPs) are representative surveys of a specific population aiming to discover what is known, believed and done in relation to a particular topic (WHO, 2008). KAPs have traditionally been carried out by aid organisations in developing countries but their advantages of speed, low cost 
and generation of quantitative data, which can be inferred on to a larger population, has meant that they have been adopted on mass and are a frequently used tool to assess both public and professional populations (Hausmann-Muela, Ribera, \& Nyamong, 2003; Launiala, 2009). They can reveal widespread misunderstandings, misconceptions and obstacles to implementation or adherence of a policy or programme (Cabana et al., 1999).

\section{Aims}

The aim of this systematic review was to identify the barriers to advance care planning discussions with patients as reported by nurses and other healthcare professionals and identified in KAPs.

Several systematic reviews have focussed on either healthcare professionals' knowledge (Kermel-Schiffman \& Werner, 2017), attitudes (Ke, Huang, O'Connor, \& Lee, 2015) or practices (Jabbarian et al., 2018) towards advance care planning, mainly exploring these categories independently. The advantage of focussing on KAPs is that all domains of knowledge, attitude and practices are assessed and these can be analysed in relation to each other, exploring potential interactions. Additionally, our decision to focus on KAPs was influenced by our desire to make a methodological contribution to the field by assessing the content and quality of published KAPs and discussing their suitability for expanding our understanding of advance care planning. To our knowledge, this is the first review to explore the use of KAPs in advance care planning.

\section{Methods}

\section{Design}

This was a systematic review of the literature. The Preferred Reporting Items for Systematic Reviews and Meta-Analysis (PRISMA) statement was used to guide the review (Moher et al., 2015) (See Supplementary File 1). A review protocol was registered in PROSPERO: registration number CRD42018055253. 


\section{Research questions}

The review was guided by the following questions:

- Have KAPs been carried out on healthcare professionals in regard to advance care planning?

- What were the barriers to advance care planning in terms of knowledge, attitudes and practice for healthcare professionals and are there interactions between these?

- What is the methodology and quality of KAPs assessing healthcare professionals' in regard to advance care planning?

\section{Search Strategy}

The authors, one social scientist (CVP) and four clinicians (DHB, DW, MGM and RMT), conducted a review of peer-reviewed journal articles using multiple databases between February and April 2018: MEDLINE, Embase, CINAHL Plus, Web of Science and Proquest Central. Additionally, the grey literature was searched using the databases OpenGrey and Trip. The search used a combination of keywords and subject headings for the concepts of KAPs, healthcare professionals and advance care planning / end of life decision making (example search strategy in supporting information). Results were combined into Mendeley, and duplicates were removed. The reference lists of included articles were screened to identify additional relevant publications.

\section{Study selection}

Two authors (CVP and DB) screened the articles in three phases (title and article type (DB), abstract (CVP and DB) and full text (CVP and DB)) based on the following criteria:

- They fulfilled the criteria of a KAPs,

- They focussed on healthcare professionals, and,

- They investigated advance care planning / end of life discussions. 
When there was disagreement the reviewers discussed their responses until agreement was reached.

The authors adopted USAID's definition of a Knowledge, Attitudes and Practice study as "a quantitative method (predefined questions formatted in standardized questionnaires) that provides access to quantitative and qualitative information" (USAID, 2011). Studies which did not meet this definition or did not look at all three domains of knowledge, attitudes and practice were excluded.

The authors adopted a definition of healthcare professionals as "individuals who maintain health in humans through the application of the principles of evidence-based medicine and caring". This has been adapted from a definition previously used by the WHO (WHO, 2013). The aim of this review was to include all those who may have advance care planning conversations with patients and so the definition of healthcare professionals was as broad as possible.

This review looked at advance care planning discussions which necessitates that these are conversations about future care. Advance care planning is related to, but distinct from, shared decision making, which aims to combine a healthcare professionals' expertise with a patient's values and goals in order to make a treatment decision(NHS England, 2018). Advance care planning takes place in the context of an anticipated deterioration in an individual's condition, where there is a concern that they will be unable to offer views or make decisions at a later time (NHS Improving Quality, 2014). In different countries, differing terminology is used to describe advance care planning. A broad definition of advance care planning would be as "a process of discussion between an individual, their care providers, and often those close to them, about future care" (Royal College of Physicians et al., 2009). For the purposes of this review advance care planning is used to describe the process of discussion, 
which may or may not result in a written document, and the term advance directive shall refer to any documentation of values, goals, concerns and/or preferences. Every effort was made to include all studies which looked at this concept regardless of terminology.

We did not exclude articles based on publication date but had to limit the selection to articles published in English.

\section{Data extraction}

Study data were collected and managed using a data extraction form developed in Microsoft Excel. The form was developed after the initial screening of full-text articles. The principal categories used in this form were knowledge, attitudes and practice. Nine (Beck et al., 2017; Downe-Wamboldt, Butler, \& Coughlan, 1998; Jezewski \& Feng, 2007; Jezewski, Meeker, \& Schrader, 2003; Lipson, Hausman, Higgins, \& Burant, 2004; Putman-Casdorph, Drenning, Richards, \& Messenger, 2009; Scherer, Jezewski, Graves, Wu, \& Bu, 2006; Sellars et al., 2015; Zhou, Stoltzfus, Houldin, Parks, \& Swan, 2010) of the eleven studies divided either the questionnaire or their results sections into these categories which guided data extraction. For those which did not, the authors placed answers in the category they felt was most appropriate.

\section{Data synthesis}

Data were exported from the spreadsheet and the main article characteristics collated and presented. As multiple different questionnaires were used with a wide degree of variation in terms of questions and topics covered it was not possible to undertake meta-analysis or other statistical techniques. Instead the authors used a qualitative approach. Articles were analysed using thematic analysis (Braun \& Clarke, 2006) to allow for the identification of patterns across the data set. A broadly descriptive type of thematic analysis was employed when developing the themes. DB read the articles numerous times to ensure immersion making initial notes of potentially interesting aspects. Following from 
this, the entire data set was coded by DB. A review of the coding of the dataset, including the codes used, was performed by CVP. The dataset was then reread and recoded with codes added, modified or removed as required to ensure the dataset was coded consistently. Potential themes were then identified with relevant data collected under each theme. The quality of studies was assessed and reported separately.

\section{Quality assessment}

Currently there is no commonly used reporting guideline for survey research, although multiple checklists have been described and/or used in the literature (Bennett et al., 2011). Bennett et al. (2011) reviewed the availability of guidance for reporting survey research from major journals as well as reviewing published studies on the quality of survey reporting. From this, 33 items were identified as critical to reporting survey research. Each of these was used to assess the articles included in the review. Articles which reported $>75 \%$ of these criteria were rated good; $50-75 \%$ moderate and $<50 \%$ poor.

\section{Results}

\section{Identification of studies}

The initial search yielded 2,217 articles (206 from CINAHL, 482 from EMBASE, 634 from Proquest, 238 from PubMed, 640 from Web of Science, 1 from OpenGrey and 16 from Trip). Once duplicates were removed, there were a total of 1,388 articles. These were screened based on title of article, resulting in 66 (Figure 1). Screening based on abstracts left 24 articles for full text review. Screening of the full texts led to 11 articles meeting the inclusion criteria. A review of the references of the articles did not find any further articles which met the inclusion criteria.

One study (Snyder et al., 2013) did not ask respondents questions about their knowledge of advance care planning. This study had a broader remit exploring the knowledge, attitudes and experience of physicians in regard to palliative 
care and hospice care in addition to advance care planning. The authors discussed the inclusion of this study and felt that although the lack of knowledge questions about advance care planning was a limitation the study still met the inclusion criteria of being a KAPs and investigating advance care planning and therefore should be included.

\section{Study characteristics}

The characteristics and results of the 11 studies included in the review are presented in Table 1. Eight of the articles originated in the USA, one was from Canada, one from Australia and one from Ireland. Despite searching the grey literature, no articles were found which met the inclusion criteria. The participants included nurses (eight), primary care physicians (one), home care package managers' (one) and nursing home managers (one).

All studies were self-administered questionnaires either on paper (nine) or online (two). The majority (ten) used a mixture of closed and open-ended questions, however one study used purely closed questions (Sellars et al., 2015). Eight studies described newly developed or modified instruments (Beck et al., 2017; Downe-Wamboldt et al., 1998; Duke et al., 2007; Jezewski et al., 2005; Lipson et al., 2004; Sellars et al., 2015; Snyder et al., 2013; Zhou et al., 2010) whilst the other three used one of these eight instruments. A description of how survey instruments were developed and how validity and reliability were established is provided in

\footnotetext{
1 Home care package services are funded by the Australian Government to facilitate the provision of personal support and clinical care services to elderly clients (aged $>65$ years) so that they can remain at home for as long as possible. Case managers, in collaboration with the client and family, coordinate and reviews the care services the clients receive.
} 
Table 2.

\section{Quality Assessment}

The 33 items identified as critical to reporting survey research by Bennett et.al were assessed for the 11 included studies by DB and the results are presented in Iable 3. One study was rated as of good quality (Lipson et al., 2004) and the rest of moderate quality. Three studies provided the full questionnaire whilst seven provided core questions and only one failed to provide either. Five newly developed, or modified, instruments reported both the validity and reliability, one reported validity only, one reported reliability only and one reported neither. Three studies used a previous instrument and referenced the original paper reporting both validity and reliability. All studies reported the response rate and ten defined how this was calculated. Three studies discussed the representativeness of the sample, and five identified how missing data were handled.

\section{Knowledge healthcare professionals have about advance care planning}

Nurses rated themselves and scored highly on the more general questions about advance care planning/advance directives including definitions and purpose (Jezewski \& Feng, 2007; Jezewski et al., 2005; Lipson et al., 2004; PutmanCasdorph et al., 2009; Scherer et al., 2006; Zhou et al., 2010) whilst nursing home managers and home care package case managers scored poorly and lacked confidence in their levels of knowledge (Beck et al., 2017; Sellars et al., 2015). Questions about specific legislation whether that be national or state were typically answered poorly by all (Beck et al., 2017; Downe-Wamboldt et al., 1998; Jezewski \& Feng, 2007; Jezewski et al., 2005; Putman-Casdorph et al., 2009; Scherer et al., 2006; Zhou et al., 2010). 


\section{Attitudes of healthcare professionals to advance care planning}

Overall healthcare professionals had a positive attitude towards advance care planning/advance directives (Downe-Wamboldt et al., 1998; Duke et al., 2007; Lipson et al., 2004; Sellars et al., 2015; Zhou et al., 2010) believing they were helpful (Downe-Wamboldt et al., 1998; Duke et al., 2007), valuable and worthwhile (Sellars et al., 2015) although one study involving acute care and outpatient oncology nurses reported moderately negative attitudes (PutmanCasdorph et al., 2009). Three studies (Jezewski \& Feng, 2007; Jezewski et al., 2005; Lipson et al., 2004) found that nurses agreed that patients should have the right to refuse treatment even if to do so would lead to death and that patients should always be informed of their condition and treatment alternatives. A participant in one study (Downe-Wamboldt et al., 1998) expressed difficulty when dealing with an advance directive when "you don't agree with the decision" but three other studies (Jezewski \& Feng, 2007; Jezewski et al., 2005; Scherer et al., 2006) found a high level of agreement for the principle that nurses should uphold patients decisions even if they disagree. Two studies (DowneWamboldt et al., 1998; Putman-Casdorph et al., 2009) found agreement that nurses consider advance care planning discussions as part of their role, whilst the studies involving home care package case managers (Sellars et al., 2015) and nursing home managers (Beck et al., 2017) found around half agreeing that it was part of their responsibilities. Interestingly, the one study which focussed on physicians found that they felt that it was patients and/or families who erect barriers to successful advance care planning conversations. The study involving nursing home managers (Beck et al., 2017) found that they felt that their patients do not want to know about future options and that around a third felt advance care planning discussions may negatively impact a patient's sense of hope. 


\section{Current practices of healthcare professionals in advance care planning}

Studies demonstrated varying levels of experience of advance care planning/advance directives with one finding $72 \%$ of nurses claiming no experience with advance directives at all (Downe-Wamboldt et al., 1998) whilst others found between $56-98 \%$ had cared for patients with an advance directive (Duke et al., 2007; Jezewski \& Feng, 2007; Scherer et al., 2006). Two studies found over $75 \%$ of nurses had initiated an advance care planning conversation with a patient (Jezewski \& Feng, 2007; Scherer et al., 2006). The study involving home care package case managers found $70 \%$ had initiated an advance care planning conversation in the last 12 months, although most of these did not progress to the documentation of wishes (Sellars et al., 2015). Physicians reported only having advance care planning discussions with $43 \%$ of patients who were chronically ill and $63 \%$ of patients who were terminally ill (Snyder et al., 2013).

In three studies, participants expressed concern that patients' wishes would not be respected despite having an advance directive (Downe-Wamboldt et al., 1998; Duke et al., 2007; Snyder et al., 2013). In another three studies (Jezewski \& Feng, 2007; Jezewski et al., 2005; Scherer et al., 2006), 17-48\% of nurses reported having provided treatment prohibited by an advance directive themselves, whilst 42-63\% had witnessed another healthcare professionals doing so.

Seven studies highlighted insufficient time as a major barrier to having advance care planning discussions with patients (Beck et al., 2017; Jezewski \& Feng, 2007; Jezewski et al., 2005; Scherer et al., 2006; Sellars et al., 2015; Snyder et al., 2013; Zhou et al., 2010). A lack of knowledge and training were also identified by nursing home managers and home care package case managers as a reason for these conversations not taking place (Beck et al., 2017; Sellars et al., 2015). Staff discomfort and the difficult nature of talking about death was mentioned in two studies (Beck et al., 2017; Zhou et al., 2010) and a lack of knowledge or 
desire on the part of patients and families was described in four (Jezewski et al., 2005; Scherer et al., 2006; Sellars et al., 2015; Zhou et al., 2010).

\section{Interactions of knowledge, attitudes and practice}

Nine studies (Beck et al., 2017; Duke et al., 2007; Jezewski \& Feng, 2007; Jezewski et al., 2003; Lipson et al., 2004; Putman-Casdorph et al., 2009; Scherer et al., 2006; Snyder et al., 2013; Zhou et al., 2010) reported on the interactions between knowledge, attitudes and practice. Six studies showed a relationship between having greater knowledge and either having a more positive attitude (Beck et al., 2017; Jezewski \& Feng, 2007; Lipson et al., 2004), greater self-reported practice of advance care planning (Lipson et al., 2004; Zhou et al., 2010), or higher levels of comfort when having such discussions (Duke et al., 2007; Lipson et al., 2004; Scherer et al., 2006). Two studies reported that greater experience of advance care planning discussions resulted in greater confidence (Jezewski et al., 2005; Putman-Casdorph et al., 2009), more positive attitudes (Jezewski et al., 2005) and a greater perception of these discussions as being part of a nursing role (Putman-Casdorph et al., 2009). One study showed no correlation between physicians reported comfort levels with advance care planning and their reported number of referrals to hospice or palliative care (Snyder et al., 2013).

\section{Discussion}

A major goal of governments and policy makers across the world is to work towards a 'shared decision making model' for healthcare as evidenced by legislation (11 1 th Congress, 2010) and guidelines (National Institute for Health and Care Excellence (NICE), 2012). For those patients who lack capacity to make a medical decision, having previously engaged in advance care planning allows these decisions to be taken with an understanding of their wishes, values and preferences. Given that uptake of advance care planning remains low, discovering obstacles which may be preventing implementation of 
advance care planning by healthcare professionals is critical if patients are to influence their treatment decisions when unwell and lacking capacity.

Many studies identified additional education and training as necessary for healthcare professionals in order to undertake advance care planning (Beck et al., 2017; Downe-Wamboldt et al., 1998; Duke et al., 2007; Jezewski \& Feng, 2007; Jezewski et al., 2005; Lipson et al., 2004; Putman-Casdorph et al., 2009; Snyder et al., 2013). Nurses tended to know about the generalities of advance care planning but lacked an in-depth knowledge of the law. This is understandable, however, at times the lack of knowledge was so great that it could undermine the process of advance care planning. For instance, in one study only $7 \%$ of respondents were aware of the competency requirements for an advance directive and only $30 \%$ the witness requirements (Duke et al., 2007). Whilst indepth knowledge of legal nuance cannot be expected, a basic level of understanding, including how to help a patient write a valid advance directive, is necessary. Nursing home managers and home care package case managers were found to be less knowledgeable than nursing staff. This is concerning, as in some contexts they may be in a good position to start such advance care planning discussions given that they have prolonged contact with patients, developing relationships with them and their families. This should make patients more comfortable when having these conversations.

Whilst not universal, it was found that healthcare professionals were broadly supportive of advance care planning and felt it was valuable for their patients. This meant that if appropriate time and training were available, they would be amenable to assisting patients with advance care planning. Even though there were some exceptions, negative attitudes of healthcare professionals do not appear to be a significant barrier to advance care planning discussions. The finding must be caveated with the knowledge that a degree of 'courtesy bias', where respondents provide the answers which they feel they 'should give' (Warwick, 1983, p. 236), may be present given the high profile support for 
advance care planning amongst healthcare leaders. The surveys were anonymous in an attempt to mitigate this risk, however some respondents may still feel pressured to give what they perceive as the 'correct' answer. Additionally, none of the studies asked respondents to rank how important they felt advance care planning was in relation to other tasks and roles. It is possible that healthcare professionals may believe that advance care planning is positive and useful, but also think that it is of a much lower priority, or urgency, than other duties.

Following from this, the most common barrier identified by healthcare professionals was a lack of time to have these discussions. Advance care planning is now 'billable' in the USA with the 'Current Procedural Terminology' providing two codes; advance care planning, first 30 minutes, and advance care planning, each additional 30 minutes (American Medical Association, 2018). This suggests that at minimum advance care planning should take half an hour and may often last longer. In the context of a busy inpatient or clinic setting it may not be possible to dedicate this amount of time to one patient. The fact that the length of these discussions is unpredictable makes it additionally difficult for them to be scheduled within the working day. It may be that the fee-for-service model is better at promoting these discussions than a bundled payment or single provider model where communication may be seen as of lower priority compared to service delivery. Alternatively, a fee-for-service approach may turn the advance care planning discussion into a tick box exercise which focusses on provider as opposed to patient priorities.

Some healthcare professionals did admit to discomfort and difficulty talking about end of life issues and some reported negative experiences either having advance care planning conversations or following a patient's advance directive. The majority of healthcare professionals, however, did feel comfortable and confident to engage in advance care planning and feelings of personal uneasiness was not seen as a major barrier. Conversely, the 
expectation of advance care planning causing discomfort to either the patient or their relatives, was more commonly cited as a block on having these discussions. Whether this is accurate or whether healthcare professionals use this fear of causing distress as an excuse for avoiding advance care planning is not possible to ascertain from survey research alone. Additional research will need to be undertaken to explore the perceptions of patients in relation to having advance care planning discussions and their experiences of engaging in these conversations.

The most concerning finding of this review was that of healthcare professionals reporting that either themselves, or another, had acted against a patient's advance directive. Healthcare professionals must respect the wishes of patients as expressed through advance directives for the process of advance care planning to have any credibility, not to mention that ignoring or subverting an advance directive is both bad professional practice and, in some cases, illegal. In 2017, a UK hospital trust was successfully sued for the artificial prolongation of a patient's life against her expressed wishes as set out in an advance directive (Paduano, 2017).

There is a requirement for greater education and training of nurses, and others, to help them understand both advance directives and the advance care planning process. In particular, it is important for nursing staff to be aware of their legal and professional obligations in order to protect patients, but also to ensure they do not face punishment themselves. The fact that most studies found a positive attitude towards advance care planning would suggest that this education and training would be met with enthusiasm as opposed to resistance. As one of the barriers to advance care planning is effective communication, healthcare professionals in a position where these are required should be required to undertake advanced communication training. Training alone, however, will not be sufficient. There is a need for institutional and financial support if advance care planning is to become routine practice. In 
particular, nurses need to be provided with adequate time, both to attend training and to have these conversations with patients in practice.

One of our goals was to evaluate the methodology and quality of KAPs in order to assess their usefulness outlining barriers to advance care planning. The major barriers we identified were time constraints (a practical barrier) and insufficient training and education (a knowledge barrier). It is likely that studies which only look at one domain, e.g. knowledge, will miss important factors which may be preventing nurses, and other healthcare professionals, from undertaking advance care planning discussions with patients. We also postulated that a major benefit would be the ability to assess the interactions between the knowledge, attitudes and practice of respondents. Nine of the eleven studies assessed these interactions finding that increasing knowledge and experience was associated with greater confidence and more positive attitudes. This is encouraging as it suggests there may be a virtuous circle whereby increased education and exposure to advance care planning promotes increasingly positive attitudes and a desire to incorporate it into practice. We believe that these advantages comprehensiveness and the assessment of interactions make KAPs a useful tool when exploring healthcare professional barriers to undertaking a behaviour or task. A potential disadvantage of KAPs is that they tend to eschew open-ended questions for the ease of data collection and so may not may not reveal new information or deepen understanding (Gumuchio, 2011). A potential strategy to reduce this risk would be to incorporate a KAPs into a mixed methods study which includes a qualitative component to allow for new ideas and concepts to be introduced by respondents.

This review should be interpreted with its limitations in mind. We tried to use the broadest possible search terms, however we may have missed articles that did not use these. Although all studies were KAPs and therefore focussed on knowledge, attitudes and practice there was a wide degree of variability of questions asked and topics covered. That studies from across the world were 
included is both a strength and weakness of this review. It provides as broad an outlook as possible, but the different legal and cultural considerations in different countries make it difficult to draw overarching conclusions. Survey research has intrinsic limitations such as sampling bias, meaning results may not be generalisable to those who, for whatever reason, choose not to complete a questionnaire. A second caveat which applies to all survey research is that the practice, or behaviour, described is by necessity reported practice and therefore there is always a concern about informant accuracy (Lane, 1997). As mentioned previously, there is also a lack of validated reporting guidelines with which to assess quality. We have tried to address this by using a well evidenced tool to report indicators of quality but it is not clear how many 'positive' indicators would qualify a survey as of poor, moderate or good quality and the cut offs that we chose are arbitrary.

\section{Conclusion}

This review has highlighted the barriers healthcare professionals have which prevent the widespread implementation of advance care planning as desired by governments and healthcare leaders. The two most important are lack of education and insufficient time. There appears to be support for advance care planning from healthcare professionals and they report themselves as comfortable and confident to take on this responsibility. To allow them to do so, will require a significant investment in training and a reorganisation of current practice to allow space for advance care planning within the working day. Further research should include qualitative interview-based research to explore themes which may not have come up in the self-reported surveys and observational research to assess whether current practice reflects healthcare professionals self-reporting. Research looking at patients' views of barriers to advance care planning discussions would also be interesting given that, in some cases, healthcare professionals will not engage in advance care planning 
because they feel patients will refuse to have these conversations or will find these upsetting.

\section{Relevance to Clinical Practice}

In order for advance care planning to become a routine part of clinical practice increased focus on nurses, and other healthcare professionals, training and education is required. Increased knowledge is likely to lead to more positive attitude and greater confidence to undertake these discussions with patients. Additionally, institutional and financial support is imperative to ensure that nurses, and others, are provided with the time and opportunity to have occasionally long, and often unpredictable, conversations with patients.

\section{Author Contributions}

Conception and design of review - all authors

Search strategy, study selection and data extraction - DB \& CVP

First draft of manuscript - DB

Critical revision of manuscript - all authors

All authors read and approved the final manuscript. 


\section{References}

111 th Congress. Patient Protection and Affordable Care Act. Public Law 111-148 (2010).

American Medical Association. (2018). Current Procedural Terminology / Medicare Payment Search. Retrieved September 5, 2018, from https://apps.ama-assn.org/CptSearch/user/search/cptSearch.do

American Nurses Association. (2015). Code of Ethics for Nurses With Interpretive Statements. Washington, D.C.: American Nurses Publishing.

Austin Health. (2018). Advance Care Planning Australia. Retrieved August 17, 2018, from https://www.advancecareplanning.org.au

Beck, E.-R., Mcllfatrick, S., Hasson, F., Leavey, G., R, B. E., S, M., ... Leavey, G. (2017). Nursing home manager's knowledge, attitudes and beliefs about advance care planning for people with dementia in long-term care settings: a cross-sectional survey. Journal of Clinical Nursing, 26(17-18), 26332645. https://doi.org/10.1111/jocn.13690

Bennett, C., Khangura, S., Brehaut, J. C., Graham, I. D., Moher, D., Potter, B. K., \& Grimshaw, J. (2011). Reporting guidelines for survey research: An analysis of published guidance and reporting practices. PLoS Medicine, 8(8), 1-11. https://doi.org/10.1371/journal.pmed.1001069

Braun, V., \& Clarke, V. (2006). Using thematic analysis in psychology. Qualitative Research in Psychology, 3(2), 77-101.

Briggs, L. A., \& Colvin, E. R. (2002). The nurse's role in end-of-life decision-making for patients and families. Geriatric Nursing, 23(6), 302-310.

https://doi.org/10.1067/mgn.2002.130271

Cabana, M. D., Rand, C. S., Powe, N. R., Wu, A. W., \& Wilson, M. H. (1999). Why 
Don't Physicians Follow A Framework for Improvement. Jama, Vol 282, 14581465. https://doi.org/10.1001/jama.282.15.1458

Curd, P. R. (1999). Advance Care Planning Reconsidered: Toward an Operational Definition of Outpatient Advance Care Planning. Journal of Palliative Medicine, 2(2), 157-159. https://doi.org/10.1016/B978-1416025979.10016-X

De Vleminck, A., Pardon, K., Houttekier, D., Van Den Block, L., Vander Stichele, R., \& Deliens, L. (2015). The prevalence in the general population of advance directives on euthanasia and discussion of end-of-life wishes: A nationwide survey Ethics, organization and policy. BMC Palliative Care, 14(1), 1-8. https://doi.org/10.1 186/s12904-015-0068-1

Downe-Wamboldt, B., Butler, L., \& Coughlan, S. (1998). Nurses' knowledge, experiences, and attitudes concerning living wills. The Canadian Journal of Nursing Research = Revue Canadienne de Recherche En Sciences Infirmieres, 30(2), 161-175.

Duke, G., Thompson, S., G, D., S, T., Duke, G., \& Thompson, S. (2007). Knowledge, attitudes and practices of nursing personnel regarding advance directives. International Journal of Palliative Nursing, 13(3), 109-115.

Dying Matters. (2018). Dying Matters - Raising awareness of dying, death and bereavement.

Gumuchio, S. (2011). The KAP Survey Model. Paris.

Hausmann-Muela, S., Ribera, J. M., \& Nyamong, I. (2003). DCPP Working Paper No. 14. Health-Seeking Behaviour and the Health System Response.

Jabbarian, L. J., Zwakman, M., Van Der Heide, A., Kars, M. C., Janssen, D. J. A., Van Delden, J. J., ... Korfage, I. J. (2018). Advance care planning for patients with chronic respiratory diseases: A systematic review of 
preferences and practices. Thorax, 73(3), 222-230.

https://doi.org/10.1136/thoraxjnl-2016-209806

Jezewski, M. A., \& Feng, J.-Y. (2007). Emergency nurses' knowledge, attitudes, and experiential survey on advance directives. Applied Nursing Research, 20(3), 132-139. https://doi.org/10.1016/j.apnr.2006.05.003

Jezewski, M. A., JK, B., YB, W., MA, M., Feng, J.-Y. Y., Bu, X. Y., ... Bu, X. Y. (2005). Oncology Nurses' Knowledge, Attitudes, and Experiences Regarding Advance Directives. Oncology Nursing Forum, 32(2), 319-327. https://doi.org/10.1188/05.ONF.319-327

Jezewski, M. A., Meeker, M. A., \& Schrader, M. (2003). Voices of oncology nurses: What is needed to assist patients with advance directives. CANCER NURSING, 26(2), 105-112. https://doi.org/10.1097/00002820-200304000-00003

Ke, L. S., Huang, X., O'Connor, M., \& Lee, S. (2015). Nurses' views regarding implementing advance care planning for older people: A systematic review and synthesis of qualitative studies. Journal of Clinical Nursing, 24(15-16), 2057-2073. https://doi.org/10.1111/jocn.12853

Kermel-Schiffman, I., \& Werner, P. (2017). Knowledge regarding advance care planning: A systematic review. Archives of Gerontology and Geriatrics, 73, 133-142. https://doi.org/10.1016/j.archger.2017.07.012

Lane, S. D. (1997). Television minidramas: social marketing and evaluation in Egypt. Medical Anthropology Quarterly, 11 (2), 164-182. https://doi.org/papers2://publication/uvid/66AE64A3-E735-4E52-897DDAEFB09EA252

Launiala, A. (2009). How much can a KAP survey tell us about people's knowledge, attitudes and practices? Some observations from medical anthropology research on malaria in pregnancy in Malawi. Anthropology 
Matters, 11(1), 1-20.

Lipson, A. R., Hausman, A. J., Higgins, P. A., \& Burant, C. J. (2004). Knowledge, attitudes, and predictors of advance directive discussions of registered nurses. Western Journal of Nursing Research, 26(7), 784-796. https://doi.org/10.1177/0193945904266528

Moher, D., Shamseer, L., Clarke, M., Ghersi, D., Liberati, A., Petticrew, M., ... Shekelle, P. (2015). Preferred reporting items for systematic review and metaanalysis protocols (PRISMA-P) 2015 statement. Systematic Reviews, 4(1). https://doi.org/10.1186/2046-4053-4-1

NatCen Social Research. (2013). British Social Attitudes Survery. Dying: Discussing and planning for end of life.

National Institute for Health and Care Excellence (NICE). (2012). Patient experience in adult NHS services: improving the experience of care for people using adult NHS services.

Newton, J., Clark, R., \& Ahlquist, P. (2009). Evaluation of the introduction of an advanced care plan into multiple palliative care settings. International Journal of Palliative Nursing, 15(11), 554-561. https://doi.org/10.12968/ijpn.2009.15.11.45495

NHS England. (2018). Shared Decision Making. Retrieved September 13, 2018, from https://www.england.nhs.uk/shared-decision-making/

NHS Improving Quality. (2014). Capacity, care planning and advance care planning in life limiting illness.

Nursing \& Midwifery Council (NMC). (2018). Future nurse: Standards of proficiency for registered nurses. https://doi.org/10.1111/j.14636409.1996.tb00170.x 
Paduano, M. (2017). Payout after woman was kept alive against her will.

Retrieved April 18, 2018, from http://www.bbc.co.uk/news/uk-englandcoventry-warwickshire-42240148

Putman-Casdorph, H., Drenning, C., Richards, S., \& Messenger, K. (2009). Advance directives: Evaluation of Nurses' Knowledge, Attitude, Confidence and Experience. J Nurs Care Qual, 24 (3), 250-256.

Raymont, V., Bingley, W., Buchanan, A., David, A. S., Hayward, P., Wessely, S., \& Hotopf, M. (2004). Prevalence of mental incapacity in medical inpatients and associated risk factors: cross-sectional study. Lancet, 364, 1421-1427. https://doi.org/10.1016/S0140-6736(04)17224-3

Re B (Adult: Refusal of Medical Treatment). (2002). Competant Adult Patient: Right to Refuse Life-sustaining Treatment. Medical Law Review, 10(Summer), 201-226. https://doi.org/https://doi.org/10.1093/medlaw/10.2.201

Royal College of Physicians. (2016). End of Life Care Audit - Dying in Hospital.

Royal College of Physicians, National Council for Palliative Care, British Society of Rehabilitation Medicine, British Geriatrics Society, Alzheimer's Society, Royal College of Nursing, ... Royal College of General Practitioners. (2009). Advance care planning. Concise Guidance to Good Practice, No 12. London.

Sabatino, C. P. (2010). The evolution of health care advance planning law and policy. Milbank Quarterly, 88(2), 21 1-239. https://doi.org/10.1 111 /j.1468$0009.2010 .00596 . x$

Scherer, Y., Jezewski, M. A., Graves, B., Wu, Y.-W. B., \& Bu, X. (2006). Advance directives and End-of-Llfe Decision Making: Survey of Critical Care Nurses' Knowledge, Attitude and Experience. Critical Care Nurse, 26(4), 30-40.

Sellars, M., Detering, K. M., Silvester, W., M, S., M, D. K., W, S., ... Silvester, W. 
(2015). Current advance care planning practice in the Australian community: An online survey of home care package case managers and service managers. BMC Palliative Care, 14(1), 1-7. https://doi.org/10.1186/s12904-015-0018-y

Snyder, S., Hazelett, S., Allen, K., Radwany, S., S, S., S, H., ... K, A. (2013). Physician Knowledge, Attitude, and Experience With Advance Care Planning, Palliative Care, and Hospice: Results of a Primary Care Survey. The American Journal of Hospice \& Palliative Care, 30(5), 419-424. https://doi.org/10.1177/1049909112452467

Teno, J. M., Nelson, H. L., \& Lynn, J. (1994). Advance Care Planning Priorities for Ethical and Empirical Research. Hastings Center Report, 24(6), S32-6.

The Conversation Project. (2018). The Conversation Project - Have You Had The Conversation? Retrieved August 16, 2018, from https://theconversationproject.org

USAID. (2011). The KAP Survey Model. Retrieved November 15, 2017, from https://www.spring-nutrition.org/publications/tool-summaries/kap-surveymodel-knowledge-attitudes-and-practices

Warwick, D. P. (1983). The KAP Survey: Dictates of Mission vs. Demands of Science. In M. Bulmer \& D. P. Warwick (Eds.), Social Research in Developing Countries (pp. 349-364). London: Routledge.

White, B., Tilse, C., Wilson, J., Rosenman, L., Strub, T., Feeney, R., \& Silvester, W. (2014). Prevalence and predictors of advance directives in Australia. Internal Medicine Journal, 44(10), 975-980. https://doi.org/10.1111/imj.12549

WHO. (2008). A guide to developing knowledge, attitude and practice surveys. World Health Organisation, 1-68. https://doi.org/Advocacy, communication and social mobilization for TB control: a guide to developing knowledge, 
attitude and practice surveys. WHO/HTM/STB/2008.46

WHO. (2013). Transforming and Scaling up health professionals' education and training. WHO Education Guidelines, 124.

https://doi.org/10.1017/CBO9781 107415324.004

Yadav, K. N., Gabler, N. B., Cooney, E., Kent, S., Kim, J., Herbst, N., ... Courtright, K. R. (2017). Approximately one in three us adults completes any type of advance directive for end-of-life care. Health Affairs, 36 (7), 1244-1251. https://doi.org/10.1377/hlthaff.2017.0175

Zhou, G., Stoltzfus, J. C., Houldin, A., Parks, S. M., \& Swan, B. A. (2010). Knowledge, attitudes, and practice behaviors of oncology advanced practice nurses regarding advanced care planning for patients with cancer. Oncology Nursing Forum, 37(6), E400-10. https://doi.org/10.1 188/10.ONF.E400-E410 


\section{Tables}

Table 1 Description, including results and limitations, of articles included in the review

\begin{tabular}{|c|c|c|c|c|c|c|}
\hline Authors & Country & Population & Knowledge & Attitudes & Practice & Limitations \\
\hline \multirow[t]{4}{*}{$\begin{array}{l}\text { Downe- } \\
\text { Wamboldt } \\
\text { (1998)(Downe- } \\
\text { Wamboldt et al., } \\
\text { 1998) }\end{array}$} & \multirow[t]{4}{*}{ Canada } & \multirow[t]{4}{*}{$157 / 974$ nurses } & $\begin{array}{l}\text { Nurses rated themselves as } \\
\text { a mean of } 7.4 \text { on a 1-10 } \\
\text { Likert scale (1 = very aware; } \\
10=\text { not at all aware) of } \\
\text { advance care } \\
\text { planning/advance } \\
\text { directives. }\end{array}$ & $\begin{array}{l}\text { Nurses had a mean } \\
\text { score of } 2.7 \text { on a Likert } \\
\text { scale ( } 1=\text { very helpful; } \\
10=\text { not at all helpful) } \\
\text { when asked about } \\
\text { advance directives. }\end{array}$ & $\begin{array}{l}113 / 157(72 \%) \text { nurses stated they } \\
\text { had no experience dealing with } \\
\text { advance directives. }\end{array}$ & Poor response rate. \\
\hline & & & $\begin{array}{l}133 / 157(85 \%) \text { knew the } \\
\text { meaning of power of } \\
\text { attorney for healthcare. }\end{array}$ & $\begin{array}{l}\text { Nurses had a mean } \\
\text { score of } 3 \text { on a Likert } \\
\text { scale ( } 1 \text { =very helpful; } \\
10=\text { not at all helpful) } \\
\text { when asked about the } \\
\text { use of a surrogate. }\end{array}$ & $\begin{array}{l}120 / 157(76 \%) \text { nurses stated that } \\
\text { they had no experience dealing } \\
\text { with surrogates. }\end{array}$ & \multirow[t]{3}{*}{$\begin{array}{l}\text { Respondents were } \\
\text { more highly educated } \\
\text { than the typical } \\
\text { registered nurse in } \\
\text { Nova Scotia. }\end{array}$} \\
\hline & & & \multirow[t]{2}{*}{$\begin{array}{l}128 / 157(82 \%) \text { believed } \\
\text { incorrectly that an advance } \\
\text { directive should be followed } \\
\text { in a situation in which a } \\
\text { surrogate for an } \\
\text { incompetent person } \\
\text { disagreed with the living will. }\end{array}$} & $\begin{array}{l}\text { One response reflected } \\
\text { a negative experience } \\
\text { with advance } \\
\text { directives: "It is not easy, } \\
\text { especially if you don't } \\
\text { agree with the } \\
\text { decision." }\end{array}$ & $\begin{array}{l}\text { The } 37 / 157 \text { nurses who reported } \\
\text { experience with living wills } \\
\text { indicated that the majority of their } \\
\text { patients were }>65 \text { years old. }\end{array}$ & \\
\hline & & & & $\begin{array}{l}\text { Nurses had a mean } \\
\text { score of } 9.2 \text { on a Likert } \\
\text { scale ( } 1=\text { agree strongly; } \\
10=\text { disagree strongly) } \\
\text { when asked whether } \\
\text { advance directives } \\
\text { restricted their nursing } \\
\text { practice. }\end{array}$ & $\begin{array}{l}\text { Nurses identified their role in } \\
\text { relation to living wills as advocate } \\
(n=28) \text {, combination of roles } \\
(n=11) \text {, facilitator }(n=5) \text { and } \\
\text { educator }(n=2) \text {. }\end{array}$ & \\
\hline
\end{tabular}




\begin{tabular}{|c|c|c|c|c|c|c|}
\hline & & & & $\begin{array}{l}\text { Nurses had a mean } \\
\text { score of } 9.1 \text { on a Likert } \\
\text { scale (1=agree strongly; } \\
10=\text { disagree strongly) } \\
\text { when asked whether } \\
\text { use of a surrogate } \\
\text { restricted their nursing } \\
\text { practice. } \\
\text { Nurses had a mean } \\
\text { score of } 3.3 \text { on a Likert } \\
\text { scale (1 = totally agree; } \\
10=\text { totally disagree) } \\
\text { with the statement that } \\
\text { nurses should promote } \\
\text { the use of advance } \\
\text { directives and } \\
\text { surrogates with all of } \\
\text { their patients. }\end{array}$ & $\begin{array}{l}\text { Nurses clearly identified lack of } \\
\text { knowledge, legal concerns, lack } \\
\text { of agency support, and ethical } \\
\text { concerns as perceived barriers to } \\
\text { the use of living wills in their } \\
\text { practice. }\end{array}$ & \\
\hline & & & & $\begin{array}{l}\text { Benefits ( } \mathrm{n}=7 \text { ) were } \\
\text { described for family, } \\
\text { patients, and nurses: "l } \\
\text { found a living will very } \\
\text { beneficial to the care } \\
\text { of my patients"; "Easier } \\
\text { to deal with the family, } \\
\text { patient more at ease"; } \\
\text { "being aware of } \\
\text { patient's and family's } \\
\text { wishes makes nursing } \\
\text { that person much } \\
\text { easier." }\end{array}$ & & \\
\hline $\begin{array}{l}\text { Lipson } \\
\text { (2004)(Lipson et } \\
\text { al., 2004) }\end{array}$ & USA & $\begin{array}{l}719 / 1600 \\
\text { nurses }\end{array}$ & $\begin{array}{l}\text { Nurses scored well (95-99\% } \\
\text { correct) on questions } \\
\text { referring to definitions of } \\
\text { advance directives. }\end{array}$ & $\begin{array}{l}\text { Nurses recorded } \\
\text { moderately positive } \\
\text { attitudes towards } \\
\text { advance directives (M } \\
=3.45 ; \mathrm{SD}=1.12 \text {; range } \\
\text { of } 1 \text { to } 5 \text { with } 5=\end{array}$ & $\begin{array}{l}7.3 \% \text { rated themselves as } \\
\text { extremely confident in their skill } \\
\text { level in discussing advance } \\
\text { directives with patients. } 14 \% \\
\text { reported that they were not } \\
\text { confident at all. }\end{array}$ & $\begin{array}{l}\text { Self-reporting means } \\
\text { that accuracy of } \\
\text { information is a } \\
\text { concern. }\end{array}$ \\
\hline
\end{tabular}




\begin{tabular}{|c|c|c|c|c|c|c|}
\hline & & & & $\begin{array}{l}\text { strongly agree and } 1= \\
\text { strongly disagree). }\end{array}$ & & \\
\hline & & & $\begin{array}{l}57 \% \text { nurses incorrectly } \\
\text { answered a question } \\
\text { referring to documentation } \\
\text { of signing procedures. }\end{array}$ & $\begin{array}{l}\text { Nurses disagreed that } \\
\text { advance directives } \\
\text { represent an } \\
\text { unwarranted extension } \\
\text { of the law into } \\
\text { medicine (M=1.85; SD } \\
=.81) \text {. }\end{array}$ & $\begin{array}{l}15 \% \text { had exposure to advance } \\
\text { directive information in nursing } \\
\text { school. }\end{array}$ & $\begin{array}{l}\text { Single state sample } \\
\text { limits generisability. }\end{array}$ \\
\hline & & & & $\begin{array}{l}\text { Nurses disagreed } \\
\text { prolonging life is more } \\
\text { important than } \\
\text { honouring a patient's } \\
\text { request to forgo life- } \\
\text { sustaining treatment (M } \\
=1.41 ; \mathrm{SD}=.63 \text { ). }\end{array}$ & $\begin{array}{l}\text { Higher age, greater years nursing } \\
\text { experience and higher level of } \\
\text { education correlated negatively } \\
\text { with reported levels of advance } \\
\text { directive discussions with patients. }\end{array}$ & \\
\hline $\begin{array}{l}\text { Jezewski } \\
\text { (2005)(Jezewski } \\
\text { et al., 2005) }\end{array}$ & USA & $\begin{array}{l}791 / 3840 \\
\text { oncology } \\
\text { nurses }\end{array}$ & $\begin{array}{l}\text { Nurses scores were highest } \\
\text { for the subscale assessing } \\
\text { general knowledge of } \\
\text { advance directives } \\
\text { including definitions, the role } \\
\text { of surrogates and some } \\
\text { legal issues related to } \\
\text { advance directives. For this } \\
\text { subscale the mean score } \\
\text { was } 7 \text { out of a possible } 10\end{array}$ & $\begin{array}{l}\text { Respondents disagreed } \\
\text { with statements stating } \\
\text { that advance directives } \\
\text { will lead to } \\
\text { acceptance of } \\
\text { euthanasia and that } \\
\text { denial of treatment for } \\
\text { terminally ill patients } \\
\text { because of cost is } \\
\text { acceptable. }\end{array}$ & $\begin{array}{l}17 \% \text { answered that they had } \\
\text { provided treatment to patients } \\
\text { whose advance directive } \\
\text { indicated otherwise, and } 42 \% \text { had } \\
\text { observed others providing } \\
\text { treatment to patients whose } \\
\text { advance directive indicated } \\
\text { otherwise. }\end{array}$ & $\begin{array}{l}\text { Low response rate } \\
(23 \%) \text { response rate } \\
\text { meaning that sampling } \\
\text { bias may be present. }\end{array}$ \\
\hline & & & & $\begin{array}{l}\text { High level of } \\
\text { agreement that nurses } \\
\text { should uphold the } \\
\text { patient's wishes even if } \\
\text { they conflict with the } \\
\text { nurse's own view. }\end{array}$ & $\begin{array}{l}52 \% \text { agreed nurses often have } \\
\text { insufficient time to discuss } \\
\text { advance directives with patients. } \\
\text { Only } 12 \% \text { believed that nurses } \\
\text { spend enough time discussing } \\
\text { advance directives with patients. }\end{array}$ & $\begin{array}{l}\text { Results may not be } \\
\text { generalisable to those } \\
\text { outwith the } 4 \text { states } \\
\text { surveyed. }\end{array}$ \\
\hline & & & & $\begin{array}{l}\text { High level of } \\
\text { agreement that } \\
\text { patients with decision- } \\
\text { making capacity who } \\
\text { are not terminally ill } \\
\text { should have a right to } \\
\text { refuse life support even }\end{array}$ & $\begin{array}{l}\text { Two-thirds or more of the nurses } \\
\text { were confident (scores of } 4 \text { and } 5 \\
\text { on the 5-point Likert scale) when } \\
\text { discussing advance directives with } \\
\text { patients and families and } \\
\text { answering their questions. }\end{array}$ & $\begin{array}{l}\text { Low internal } \\
\text { consistency for } \\
\text { subscales about } \\
\text { attitudes towards } \\
\text { advance directives } \\
\text { and end of life care as } \\
\text { well as professional }\end{array}$ \\
\hline
\end{tabular}




\begin{tabular}{|c|c|c|c|c|c|c|}
\hline & & & & $\begin{array}{l}\text { if that decision may } \\
\text { lead to death. }\end{array}$ & & \multirow[t]{2}{*}{$\begin{array}{l}\text { experiences with } \\
\text { advance directives. }\end{array}$} \\
\hline & & & & $\begin{array}{l}\text { High level of } \\
\text { agreement that it is } \\
\text { appropriate to give } \\
\text { medication to relieve } \\
\text { pain even if it may } \\
\text { hasten a patient's } \\
\text { death. }\end{array}$ & $\begin{array}{l}\text { The qualitative component } \\
\text { outlined the need for } \\
\text { 1) education regarding advance } \\
\text { directives } \\
\text { 2) the need for more time to assist } \\
\text { patients completing advance } \\
\text { directives } \\
\text { 3) support from administrators and } \\
\text { physicians regarding the nurse's } \\
\text { role in helping patients complete } \\
\text { advance directives }\end{array}$ & \\
\hline \multirow[t]{4}{*}{$\begin{array}{l}\text { Scherer } \\
\text { (2006) (Scherer } \\
\text { et al., 2006) }\end{array}$} & \multirow[t]{4}{*}{ USA } & \multirow[t]{4}{*}{$\begin{array}{l}210 / 1000 \\
\text { critical care } \\
\text { nurses }\end{array}$} & \multirow{4}{*}{$\begin{array}{l}\text { Nurses scores were highest } \\
\text { for the subscale assessing } \\
\text { general knowledge of } \\
\text { advance directives } \\
\text { including definitions, the role } \\
\text { of proxy decision makers } \\
\text { and some legal issues } \\
\text { related to advance } \\
\text { directives. For this subscale } \\
\text { the mean score was } 7.07 \\
\text { out of a possible } 10 \text { (70.7\%). }\end{array}$} & $\begin{array}{l}\text { Most respondents } \\
(94.8 \%) \text { agreed that } \\
\text { nurses should uphold a } \\
\text { patient's wishes even if } \\
\text { the wishes conflict with } \\
\text { the nurses' own view. }\end{array}$ & $\begin{array}{l}\text { Most of the respondents had } \\
\text { cared for a patient who had } \\
\text { advance directives ( } 98.0 \%) \text {, } \\
\text { counselled patients and patients' } \\
\text { families about advance directives } \\
\text { ( } 84.8 \% \text { ), and initiated discussion } \\
\text { with patients about advance } \\
\text { directives (82.9\%). }\end{array}$ & Low response rate. \\
\hline & & & & $\begin{array}{l}\text { The respondents felt } \\
\text { strongly }(96.1 \% \\
\text { agreement) that } \\
\text { patients should receive } \\
\text { the pain medication } \\
\text { the patients need even } \\
\text { though the medication } \\
\text { may hasten death. }\end{array}$ & $\begin{array}{l}48.1 \% \text { of nurses had provided } \\
\text { treatment to a patient whose } \\
\text { advance directive had indicated } \\
\text { otherwise. } 71.3 \% \text { of nurses had } \\
\text { witnessed others providing } \\
\text { treatment to a patient whose } \\
\text { advance directive had indicated } \\
\text { otherwise. }\end{array}$ & $\begin{array}{l}\text { Results not } \\
\text { generalisable outwith } \\
\text { New York State and } \\
\text { registered nurses. }\end{array}$ \\
\hline & & & & $\begin{array}{l}\text { Agreement was high } \\
\text { that nurses are } \\
\text { responsible for } \\
\text { conferring with a } \\
\text { physician if a patient's } \\
\text { rights have not been } \\
\text { considered. }\end{array}$ & $\begin{array}{l}59.1 \% \text { agreed nurses often have } \\
\text { insufficient time to discuss } \\
\text { advance directives with patients. } \\
\text { Only } 12.6 \% \text { believed that nurses } \\
\text { spend enough time discussing } \\
\text { advance directives with patients. }\end{array}$ & \multirow[t]{2}{*}{$\begin{array}{l}\text { Low internal } \\
\text { consistency for } \\
\text { attitudes to advance } \\
\text { directives and } \\
\text { experience with EoL } \\
\text { decision making. }\end{array}$} \\
\hline & & & & $\begin{array}{l}96.2 \% \text { agreed that } \\
\text { nurses should help } \\
\text { inform patients of their }\end{array}$ & $\begin{array}{l}\text { Respondents were most confident } \\
\text { (scores }>4 \text { ) on items dealing with } \\
\text { confidence in initiating (mean } \\
\text { score 4.06, SD 1.05) and answering } \\
\text { patients' (mean score 4.03, SD }\end{array}$ & \\
\hline
\end{tabular}




\begin{tabular}{|c|c|c|c|c|c|c|}
\hline & & & & $\begin{array}{l}\text { condition and } \\
\text { treatment options. }\end{array}$ & $\begin{array}{l}\text { 0.98) and patients' families' } \\
\text { (mean score 4.03, SD 0.96) } \\
\text { questions about advance } \\
\text { directives. }\end{array}$ & \\
\hline \multirow[t]{3}{*}{$\begin{array}{l}\text { Duke } \\
\text { (2007)(Duke et } \\
\text { al., 2007) }\end{array}$} & \multirow[t]{3}{*}{ USA } & \multirow[t]{3}{*}{$108 / 283$ nurses } & $\begin{array}{l}\text { Only } 7 \% \text { were aware of } \\
\text { competency requirements } \\
\text { for an advance directive. }\end{array}$ & \multirow[t]{3}{*}{$\begin{array}{l}80 \% \text { felt advance } \\
\text { directives were helpful. }\end{array}$} & $\begin{array}{l}56 \% \text { had assisted a patient with an } \\
\text { advance directive. }\end{array}$ & Small sample size. \\
\hline & & & \multirow[t]{2}{*}{$\begin{array}{l}42 \% \text { incorrectly thought that } \\
\text { nutrition and hydration were } \\
\text { included in comfort care. }\end{array}$} & & $\begin{array}{l}\text { In the open-ended question } 3 \\
\text { respondents expressed concerns } \\
\text { that wishes would not be } \\
\text { honoured by physicians and/or } \\
\text { families. }\end{array}$ & $\begin{array}{l}\text { New tool lacked } \\
\text { internal consistency. }\end{array}$ \\
\hline & & & & & $\begin{array}{l}74 \% \text { said they felt comfortable } \\
\text { discussing advance directives with } \\
\text { patients, } 14 \% \text { neutral and } 4 \% \\
\text { unfavourable. }\end{array}$ & $\begin{array}{l}\text { Non-probability } \\
\text { sampling. }\end{array}$ \\
\hline \multirow[t]{3}{*}{$\begin{array}{l}\text { Jezewski } \\
\text { (2007) (Jezewski } \\
\text { \& Feng, 2007) }\end{array}$} & \multirow[t]{3}{*}{ USA } & \multirow[t]{3}{*}{$\begin{array}{l}579 / 3800 \\
\text { emergency } \\
\text { nurses }\end{array}$} & \multirow{3}{*}{$\begin{array}{l}\text { Nurses scores were highest } \\
\text { for the subscale assessing } \\
\text { general knowledge of } \\
\text { advance directives } \\
\text { including definitions, the role } \\
\text { of proxy decision makers } \\
\text { and some legal issues } \\
\text { related to advance } \\
\text { directives. For this subscale } \\
\text { the mean score was } 6.8 \text { out } \\
\text { of a possible } 10(68 \%) \text {. }\end{array}$} & $\begin{array}{l}\text { High level of } \\
\text { agreement that nurses } \\
\text { should uphold the } \\
\text { patient's wishes even if } \\
\text { they conflict with the } \\
\text { nurse's own view. }\end{array}$ & $\begin{array}{l}\text { Over } 76 \% \text { answered yes to having } \\
\text { cared for a patient with an } \\
\text { advance directive, read their } \\
\text { institutional policies/procedures } \\
\text { concerning advance directives, } \\
\text { and initiated discussion about } \\
\text { advance directives with a patient. }\end{array}$ & $\begin{array}{l}\text { Low response rate } \\
(17 \%) \text {. }\end{array}$ \\
\hline & & & & $\begin{array}{l}\text { High level of } \\
\text { agreement that nurses } \\
\text { should help inform } \\
\text { patients about their } \\
\text { condition and } \\
\text { treatment alternatives. }\end{array}$ & $\begin{array}{l}40 \% \text { of the nurses had provided } \\
\text { treatment to patients whose } \\
\text { advance directive indicated } \\
\text { otherwise and } 63 \% \text { of the nurses in } \\
\text { the study had observed others } \\
\text { providing treatment to patients } \\
\text { whose advance directive } \\
\text { indicated otherwise. }\end{array}$ & $\begin{array}{l}\text { Low internal } \\
\text { consistency for } \\
\text { attitudes to advance } \\
\text { directives and EoL } \\
\text { decision making. Also, } \\
\text { there was low internal } \\
\text { consistency for the } \\
\text { subscale asking about } \\
\text { opinions based on } \\
\text { professional } \\
\text { experiences with } \\
\text { advance directives. }\end{array}$ \\
\hline & & & & $\begin{array}{l}83 \% \text { of nurses surveyed } \\
\text { agreed that the } \\
\text { presence of an } \\
\text { advance directive }\end{array}$ & $\begin{array}{l}\text { Only } 10 \% \text { believed that nurses } \\
\text { spend enough time discussing } \\
\text { advance directives with patients. }\end{array}$ & \\
\hline
\end{tabular}




\begin{tabular}{|c|c|c|c|c|c|c|}
\hline & & & & $\begin{array}{l}\text { encourages discussion } \\
\text { between patients and } \\
\text { providers. }\end{array}$ & & \\
\hline & & & & $\begin{array}{l}72 \% \text { of emergency } \\
\text { nurses agreed that } \\
\text { patients misunderstand } \\
\text { the meaning of } \\
\text { advance directives. }\end{array}$ & $\begin{array}{l}\text { Nurses were confident in } \\
\text { complying with the provisions of } \\
\text { the patient's advance directive } \\
(74 \%) \text { and advocating for } \\
\text { patients' advance directives } \\
\text { when patient wishes conflict with } \\
\text { the wishes of the family }(60 \%) \text {. }\end{array}$ & \\
\hline & & & & & $\begin{array}{l}\text { Nurses wrote most frequently } \\
\text { about the need for education } \\
\text { about advance directives and } \\
\text { the lack of time to talk with } \\
\text { patients in the emergency room } \\
\text { impacting on advance directive } \\
\text { completion. }\end{array}$ & \\
\hline \multirow[t]{3}{*}{$\begin{array}{l}\text { Putman- } \\
\text { Casdorph } \\
\text { (2009)(Putman- } \\
\text { Casdorph et al., } \\
\text { 2009) }\end{array}$} & \multirow[t]{3}{*}{ USA } & \multirow{3}{*}{$\begin{array}{l}87 / 198 \text { acute } \\
\text { care nurses } \\
\text { (general } \\
\text { medical / } \\
\text { surgical, } \\
\text { cardiac) \& } \\
\text { inpatient \& } \\
\text { outpatient } \\
\text { oncology } \\
\text { nurses }\end{array}$} & \multirow{3}{*}{$\begin{array}{l}\text { Participants scored highest } \\
\text { on general questions related } \\
\text { to advance directives such } \\
\text { as questions about the } \\
\text { purpose and function of } \\
\text { living wills and medical } \\
\text { power of attorney, with } 95 \% \\
\text { to } 100 \% \text { of participants } \\
\text { answering those questions } \\
\text { correctly. }\end{array}$} & \multirow{2}{*}{$\begin{array}{l}\text { Participants responded } \\
\text { with moderately } \\
\text { negative attitudes } \\
\text { overall toward } \\
\text { advance directives, } \\
\text { with an aggregate } \\
\text { mean score of } \\
2.21 \text { (SD }=0.84 \text { ) and a } \\
\text { range from } 1 \text { to } 5 . \\
\text { Higher mean scores } \\
\text { were consistent with } \\
\text { more positive attitudes }\end{array}$} & \multirow[t]{2}{*}{$\begin{array}{l}\text { The experience mean score for } \\
\text { the sample was } 2.52 \text { (SD = 0.83) } \\
\text { when asked "How often do you } \\
\text { participate in discussions } \\
\text { regarding advance directives with } \\
\text { your patients?". A lower mean } \\
\text { score indicated greater numbers } \\
\text { of these discussions with patients. }\end{array}$} & Small sample size. \\
\hline & & & & & & Poor response rate. \\
\hline & & & & $\begin{array}{l}\text { Participants were also } \\
\text { asked whether they } \\
\text { considered advance } \\
\text { directive discussions as } \\
\text { one of their nursing } \\
\text { roles. The mean score } \\
\text { was } 2.18 \text { (SD = 1.03), } \\
\text { with lower scores } \\
\text { indicating that these } \\
\text { discussions were part of } \\
\text { the nursing role. }\end{array}$ & $\begin{array}{l}\text { A higher mean score was } \\
\text { associated with higher rates of } \\
\text { perceived self-confidence. The } \\
\text { sample for this study had a mean } \\
\text { of } 2.63 \text { (SD = 0.78), indicating } \\
\text { slightly to moderately confident } \\
\text { perceptions. Only one participant } \\
\text { reported feeling extremely } \\
\text { confident with his or her advance } \\
\text { care planning discussion skills. The } \\
\text { majority of the sample } \\
\text { participants were either slightly }\end{array}$ & $\begin{array}{l}\text { Only representative of } \\
\text { one hospital. }\end{array}$ \\
\hline
\end{tabular}




\begin{tabular}{|c|c|c|c|c|c|c|}
\hline & & & & & $\begin{array}{l}\text { confident ( } n=23,26 \% \text { ) or } \\
\text { moderately confident ( } n=50 \text {, } \\
58 \%) \text {. }\end{array}$ & \\
\hline \multirow[t]{3}{*}{$\begin{array}{l}\text { Zhou } \\
\text { (2010)(Zhou et } \\
\text { al., 2010) }\end{array}$} & \multirow[t]{3}{*}{ USA } & \multirow[t]{3}{*}{$\begin{array}{l}89 / 300 \\
\text { oncology } \\
\text { advanced } \\
\text { practice } \\
\text { nurses }\end{array}$} & \multirow[t]{3}{*}{$\begin{array}{l}\text { The average score of all } \\
\text { respondents who answered } \\
\text { the } 12 \text {-item knowledge } \\
\text { section correctly was } 67 \% \\
\text { (range } 33 \%-92 \% \text { ), whereas } \\
\text { the majority of respondents } \\
\text { (88\%) achieved greater } \\
\text { than a } 50 \% \text { correct score. }\end{array}$} & \multirow[t]{3}{*}{$\begin{array}{l}\text { In general, respondents } \\
\text { scored positively in their } \\
\text { attitudes toward } \\
\text { advance care planning } \\
\text { (mean }=1.91, \mathrm{SD}=0.37 \text {, } \\
\text { range } 1.5-2.52 \text { ). Lower } \\
\text { scores were consistent } \\
\text { with positive attitudes. }\end{array}$} & $\begin{array}{l}\text { Respondents scored only } \\
\text { marginally positive in advance } \\
\text { care planning practice behaviour } \\
\text { statements that included initiating } \\
\text { and following-up on advance } \\
\text { care planning discussions and } \\
\text { talking about options of hospice } \\
\text { or palliative care with patients } \\
\text { with advanced cancer and their } \\
\text { families (mean }=2.62, \text { SD }=0.45 \text { ). } \\
\text { Lower scores were consistent with } \\
\text { greater experience. }\end{array}$ & Small sample size. \\
\hline & & & & & $\begin{array}{l}\text { When asked about whether they } \\
\text { had advance care planning } \\
\text { discussions with } 50 \% \text { or more of } \\
\text { patients with advanced cancer in } \\
\text { their practice, responses varied } \\
\text { greatly (mean }=3.04, S D=1.02 \text { ). } \\
\text { Lower scores represent positive } \\
\text { behaviour. }\end{array}$ & $\begin{array}{l}\text { Reliant on self- } \\
\text { reporting. }\end{array}$ \\
\hline & & & & & $\begin{array}{l}\text { When asked about how often } \\
\text { their collaborating oncologist(s) } \\
\text { initiated advance care planning } \\
\text { discussions, } 44 \% \text { said "sometimes," } \\
\text { and } 37 \% \text { said "often" (answer key } \\
=\text { never, rarely, sometimes, often, } \\
\text { always, don't know). }\end{array}$ & $\begin{array}{l}\text { Oncology APNs } \\
\text { working at different } \\
\text { practice settings may } \\
\text { have different patient } \\
\text { care foci. For example, } \\
\text { APNs not involved in } \\
\text { direct patient care or } \\
\text { already working in } \\
\text { hospice may not need } \\
\text { to practice advance } \\
\text { care planning. }\end{array}$ \\
\hline
\end{tabular}




\begin{tabular}{|c|c|c|c|c|c|c|}
\hline & & & & & & $\begin{array}{l}\text { Because advance } \\
\text { care planning is a } \\
\text { value-laden practice, } \\
\text { social desirability bias } \\
\text { also may have } \\
\text { influenced } \\
\text { respondents' choices } \\
\text { to certain survey items. }\end{array}$ \\
\hline \multirow[t]{3}{*}{$\begin{array}{l}\text { Snyder } \\
\text { (2013)(Snyder et } \\
\text { al., 2013) }\end{array}$} & \multirow[t]{3}{*}{ USA } & \multirow[t]{3}{*}{$\begin{array}{l}158 / 372 \\
\text { primary care } \\
\text { physicians }\end{array}$} & & \multirow{2}{*}{$\begin{array}{l}\text { Many physicians felt } \\
\text { that it was the patients } \\
\text { and/or families } \\
\text { themselves who erect } \\
\text { barriers to successful } \\
\text { advance care planning } \\
\text { discussions. }\end{array}$} & $\begin{array}{l}\text { 44\% percent of primary care } \\
\text { physicians expressed the opinion } \\
\text { that advance care planning } \\
\text { discussions take too much time. }\end{array}$ & Poor response rate. \\
\hline & & & & & $\begin{array}{l}\text { Physicians report discussing } \\
\text { advance directives with only } 43 \% \\
\text { of the patients they identified as } \\
\text { having progressive, chronic life- } \\
\text { limiting disease and only } 61 \% \text { of } \\
\text { patients who are terminally ill. }\end{array}$ & $\begin{array}{l}\text { Only representative of } \\
\text { single geographic } \\
\text { region. }\end{array}$ \\
\hline & & & & $\begin{array}{l}97.5 \% \text { of physicians } \\
\text { expressed comfort in } \\
\text { discussing advance } \\
\text { care planning. }\end{array}$ & $\begin{array}{l}54 \% \text { of physicians responding } \\
\text { believed that advance care } \\
\text { planning should begin near } \\
\text { disease onset, whereas only } 4 \% \\
\text { believe this is when advance care } \\
\text { planning actually occurs. }\end{array}$ & $\begin{array}{l}\text { No questions asking } \\
\text { about knowledge of } \\
\text { advance care } \\
\text { planning were asked. }\end{array}$ \\
\hline \multirow[t]{2}{*}{$\begin{array}{l}\text { Sellars } \\
(2015) \text { (Sellars et } \\
\text { al., 2015) }\end{array}$} & \multirow[t]{2}{*}{ Australia } & \multirow[t]{2}{*}{$\begin{array}{l}\text { 178/962 home } \\
\text { care package } \\
\text { case } \\
\text { managers }\end{array}$} & \multirow{2}{*}{$\begin{array}{l}<50 \% \text { felt confident } \\
\text { regarding their knowledge } \\
\text { and skills on eight advance } \\
\text { care planning domains e.g. } \\
\text { answering questions about } \\
\text { advance care planning, } \\
\text { knowing laws etc. }\end{array}$} & $\begin{array}{l}75 \% \text { believed advance } \\
\text { care planning was } \\
\text { valuable and } \\
\text { worthwhile for clients. }\end{array}$ & $\begin{array}{l}70 \% \text { had initiated an advance } \\
\text { care planning conversation in the } \\
\text { previous } 12 \text { months, but } 80 \% \text { of the } \\
\text { conversations did not progress to } \\
\text { documentation of wishes. }\end{array}$ & Poor response rate. \\
\hline & & & & $\begin{array}{l}74 \% \text { believed clients } \\
\text { were more comfortable } \\
\text { discussing advance } \\
\text { care planning and EOL } \\
\text { care in their own home. }\end{array}$ & $\begin{array}{l}65 \% \text { were not satisfied with the } \\
\text { time allowed to undertake } \\
\text { advance care planning, } 60 \% \text { with } \\
\text { lack of support from senior staff, } \\
67 \% \text { with the lack of appropriate } \\
\text { documentation for recording } \\
\text { outcomes, } 78 \% \text { with the lack of } \\
\text { training and } 72 \% \text { with the lack of } \\
\text { written material to give to service } \\
\text { users and their families. }\end{array}$ & $\begin{array}{l}\text { Reliant on self- } \\
\text { reporting. }\end{array}$ \\
\hline
\end{tabular}




\begin{tabular}{|c|c|c|c|c|c|c|}
\hline & & & & $\begin{array}{l}55 \% \text { of case managers } \\
\text { believed that they had } \\
\text { a role in advance care } \\
\text { planning. }\end{array}$ & $\begin{array}{l}\text { Only } 27 \% \text { believed that the } \\
\text { majority of clients were interested. } \\
66 \% \text { felt comfortable discussing } \\
\text { advance care planning with } \\
\text { clients. Only } 12 \% \text { reported having } \\
\text { a negative experience of } \\
\text { advance care planning. }\end{array}$ & $\begin{array}{l}\text { Risk of social desirability } \\
\text { bias. }\end{array}$ \\
\hline & & & & & $\begin{array}{l}\text { Only } 48 \% \text { ( } n=85 \text { ) had previously } \\
\text { completed any advance care } \\
\text { planning training and only } 30 \% \\
(n=25) \text { had that funded by their } \\
\text { employer. }\end{array}$ & \\
\hline \multirow[t]{3}{*}{$\begin{array}{l}\text { Beck } \\
(2017)(\text { Beck et } \\
\text { al., 2017) }\end{array}$} & \multirow[t]{3}{*}{ Ireland } & \multirow[t]{3}{*}{$\begin{array}{l}116 / 178 \\
\text { nursing home } \\
\text { mangers }\end{array}$} & $\begin{array}{l}\text { The results demonstrated } \\
\text { that nursing home } \\
\text { managers' knowledge of } \\
\text { advance care planning was } \\
\text { poor, with less than half the } \\
\text { sample }(47 \% n=54) \text { being } \\
\text { able to respond correctly to } \\
\text { more than three of the } \\
\text { seven knowledge questions. }\end{array}$ & $\begin{array}{l}\text { Respondents } \\
\text { highlighted the difficulty } \\
\text { for nursing home } \\
\text { managers in discussing } \\
\text { death, with one } \\
\text { participant stating } \\
\text { 'death is a tough } \\
\text { subject'. }\end{array}$ & $\begin{array}{l}\text { Less than half of nursing home } \\
\text { managers perceived it to be their } \\
\text { role }(47 \% \mathrm{n}=54)\end{array}$ & $\begin{array}{l}\text { Self-reporting means } \\
\text { that accuracy of } \\
\text { information is a } \\
\text { concern. }\end{array}$ \\
\hline & & & \multirow[t]{2}{*}{$\begin{array}{l}\text { advance care planning was } \\
\text { viewed incorrectly as a } \\
\text { legally binding document } \\
(41 \% \mathrm{n}=48 \text { ), related only to } \\
\text { medical interventions ( } 50 \% \mathrm{n} \\
=58 \text { ) with little recognition of } \\
\text { the voluntary nature of the } \\
\text { process. }\end{array}$} & $\begin{array}{l}\text { Barriers to advance } \\
\text { care planning identified } \\
\text { included: } \\
\text { 1) lack of knowledge } \\
\text { 2) time constraints } \\
\text { 3) family conflict and } \\
\text { the desire to protect } \\
\text { the person from harm. }\end{array}$ & \multirow[t]{2}{*}{$\begin{array}{l}\text { Those who had attended specific } \\
\text { advance care planning training } \\
\text { ( } 24 \% n=28 \text { ) did not have } \\
\text { improved knowledge as a result } \\
\text { but they were likely to have a } \\
\text { more positive attitude towards } \\
\text { advance care planning. }\end{array}$} & $\begin{array}{l}\text { Acknowledged risk of } \\
\text { response bias. }\end{array}$ \\
\hline & & & & $\begin{array}{l}\text { There was an } \\
\text { assumption that people } \\
\text { with dementia }(81 \% \mathrm{n}= \\
\text { 94) do not want to }\end{array}$ & & \\
\hline
\end{tabular}




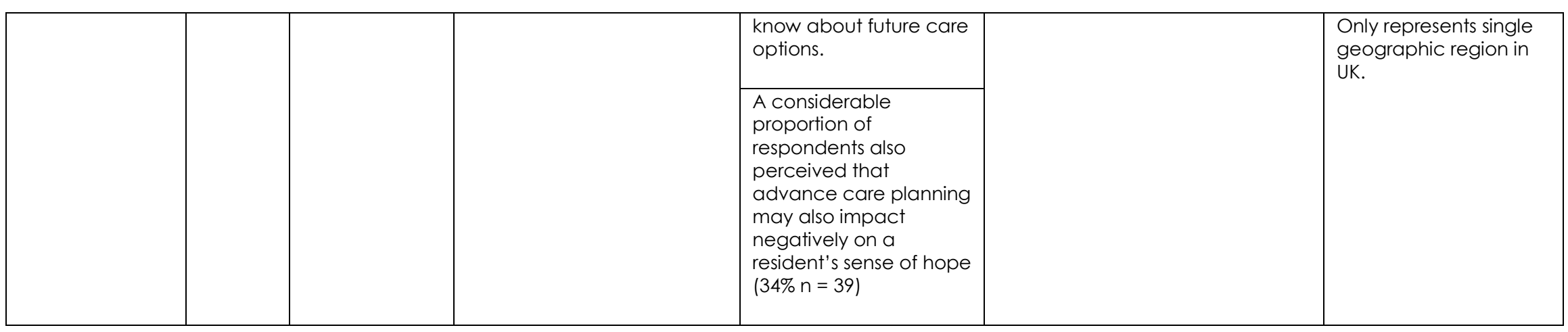


Table 2 Description of questionnaire development for Knowledge, Attitudes and Practice studies included in the review

\begin{tabular}{|c|c|c|c|c|c|c|c|c|}
\hline & $\begin{array}{l}\text { Downe- } \\
\text { Wamboldt } \\
\text { (1998) }\end{array}$ & Lipson (2004) & Jezewski (2005) & Duke (2007) & Zhou (2010) & $\begin{array}{l}\text { Snyder } \\
\text { (2013) }\end{array}$ & Sellars (2015) & Beck (2017) \\
\hline $\begin{array}{l}\text { How was the } \\
\text { instrument } \\
\text { developed? }\end{array}$ & $\begin{array}{l}\text { New instrument } \\
\text { developed by } \\
\text { author. Based } \\
\text { on literature } \\
\text { review and using } \\
9 \text { questions from } \\
\text { a previous piece } \\
\text { of work 'Medical } \\
\text { Consent Act' } \\
\text { survey. }\end{array}$ & $\begin{array}{l}\text { New instrument } \\
\text { developed by } \\
\text { author. } \\
\text { Amalgamated } \\
3 \text { previously } \\
\text { used } \\
\text { questionnaires } \\
\text { as well as new } \\
\text { author } \\
\text { developed } \\
\text { items. }\end{array}$ & $\begin{array}{l}\text { New instrument } \\
\text { developed by } \\
\text { author. Unclear } \\
\text { how it was } \\
\text { developed. }\end{array}$ & $\begin{array}{l}\text { New } \\
\text { instrument } \\
\text { developed by } \\
\text { author. Based } \\
\text { on literature on } \\
\text { the attitudes } \\
\text { and practices } \\
\text { of nursing } \\
\text { personnel } \\
\text { regarding } \\
\text { advance } \\
\text { directives, } \\
\text { round table } \\
\text { discussion with } \\
\text { practicing } \\
\text { nurses and the } \\
\text { legislative } \\
\text { mandates } \\
\text { found in the } \\
\text { PSDA and in } \\
\text { Texas laws on } \\
\text { advance } \\
\text { directives. }\end{array}$ & $\begin{array}{l}\text { New instrument } \\
\text { developed by author. } \\
\text { Developed using } \\
\text { Azjen's 'Theory of } \\
\text { Planned Behaviour' as } \\
\text { theoretical base. } \\
\text { Questions were taken } \\
\text { from previously } \\
\text { developed surveys, } \\
\text { developed using } \\
\text { author's experience as } \\
\text { Oncology APN and } \\
\text { several hospice and } \\
\text { palliative experts } \\
\text { recommendations. }\end{array}$ & $\begin{array}{l}\text { New } \\
\text { instrument } \\
\text { developed } \\
\text { by author. } \\
\text { Unclear how } \\
\text { it was } \\
\text { developed. }\end{array}$ & $\begin{array}{l}\text { New } \\
\text { instrument } \\
\text { developed } \\
\text { by author. } \\
\text { Based on } \\
\text { literature } \\
\text { and authors } \\
\text { previous } \\
\text { research. }\end{array}$ & $\begin{array}{l}\text { The Zhou } \\
\text { instrument } \\
\text { was adapted } \\
\text { to fit with the } \\
\text { different } \\
\text { context of } \\
\text { care home } \\
\text { managers. }\end{array}$ \\
\hline $\begin{array}{l}\text { How many } \\
\text { items were in } \\
\text { the } \\
\text { instrument? }\end{array}$ & $\begin{array}{l}\text { Not provided. } \\
\text { Described as 12- } \\
\text { page survey. }\end{array}$ & 52 & 115 & 40 & 52 & 30 & 46 & 48 \\
\hline $\begin{array}{l}\text { What were } \\
\text { the type of } \\
\text { quantitative }\end{array}$ & True / False & True / False & $\begin{array}{l}\text { Yes / No / Don't } \\
\text { know }\end{array}$ & Not reported. & Multiple choice & $\begin{array}{l}\text { Multiple } \\
\text { choice }\end{array}$ & $\begin{array}{l}\text { Multiple } \\
\text { choice }\end{array}$ & $\begin{array}{l}\text { True / False / } \\
\text { Don't know }\end{array}$ \\
\hline
\end{tabular}




\begin{tabular}{|c|c|c|c|c|c|c|c|c|}
\hline \multirow[t]{2}{*}{$\begin{array}{l}\text { questions } \\
\text { used? }\end{array}$} & Yes / No & Yes / No & \multirow[t]{2}{*}{ Likert scales } & & \multirow[t]{2}{*}{ Likert scales } & $\begin{array}{l}\text { Asked to } \\
\text { provide a } \\
\text { percentage }\end{array}$ & \multirow[t]{2}{*}{ Likert scales } & \multirow[t]{2}{*}{ Likert scales } \\
\hline & Likert scales & Likert scales & & & & Likert scales & & \\
\hline $\begin{array}{l}\text { What were } \\
\text { the type and } \\
\text { number of } \\
\text { quantitative } \\
\text { questions } \\
\text { used? }\end{array}$ & $\begin{array}{l}\text { Unknown } \\
\text { number of open- } \\
\text { ended questions. }\end{array}$ & $\begin{array}{l}2 \text { open-ended } \\
\text { questions. }\end{array}$ & $\begin{array}{l}1 \text { open ended } \\
\text { question. }\end{array}$ & $\begin{array}{l}1 \text { open ended } \\
\text { question. }\end{array}$ & $\begin{array}{l}7 \text { open-ended } \\
\text { questions. }\end{array}$ & $\begin{array}{l}1 \text { open- } \\
\text { ended } \\
\text { question. }\end{array}$ & None. & $\begin{array}{l}3 \text { open- } \\
\text { ended } \\
\text { questions. }\end{array}$ \\
\hline $\begin{array}{l}\text { How was } \\
\text { validity } \\
\text { established? }\end{array}$ & $\begin{array}{l}\text { Content validity } \\
\text { and clarity were } \\
\text { assessed by a } \\
\text { multidisciplinary } \\
\text { panel of experts } \\
\text { (lawyer, nurse, } \\
\text { social worker). }\end{array}$ & $\begin{array}{l}\text { The modified } \\
\text { survey was } \\
\text { evaluated for } \\
\text { content validity } \\
\text { by topic experts } \\
\text { (two nurse- } \\
\text { attorneys, one } \\
\text { attorney } \\
\text { specializing in } \\
\text { elder la, and } \\
\text { five nurses) }\end{array}$ & $\begin{array}{l}\text { Content validity was } \\
\text { evaluated by an } \\
\text { expert panel. The } \\
\text { panel members } \\
\text { were experts in end- } \\
\text { of-life care and } \\
\text { advance directives } \\
\text { and represented } \\
\text { the disciplines of } \\
\text { nursing, medicine, } \\
\text { law, and bioethics. } \\
\text { The panel provided } \\
\text { feedback on each } \\
\text { of the } 110 \text { items } \\
\text { included in the } \\
\text { original draft of the } \\
\text { survey. Changes } \\
\text { were made to } 22 \\
\text { items. Nine items } \\
\text { were added, and } \\
\text { four items were } \\
\text { deleted based on } \\
\text { the opinions of the } \\
\text { panel and the } \\
\text { judgment of the } \\
\text { authors. }\end{array}$ & $\begin{array}{l}\text { Content } \\
\text { validity was } \\
\text { determined } \\
\text { with a panel of } \\
\text { five experts in } \\
\text { nursing } \\
\text { research and } \\
\text { end of life } \\
\text { care. }\end{array}$ & $\begin{array}{l}\text { Content validity } \\
\text { established by panel } \\
\text { of } 5 \text { academic } \\
\text { researchers and } \\
\text { palliative care experts } \\
\text { from several } \\
\text { academic and } \\
\text { clinical institutions. }\end{array}$ & $\begin{array}{l}\text { Not } \\
\text { established. }\end{array}$ & $\begin{array}{l}\text { Not } \\
\text { established. }\end{array}$ & $\begin{array}{l}\text { Content } \\
\text { validity } \\
\text { established } \\
\text { by 7-person } \\
\text { panel } \\
\text { consisting of } \\
\text { experts in } \\
\text { gerontology, } \\
\text { palliative } \\
\text { care and/or } \\
\text { dementia. }\end{array}$ \\
\hline
\end{tabular}




\begin{tabular}{|c|c|c|c|c|c|c|c|}
\hline $\begin{array}{l}\text { How was } \\
\text { reliability } \\
\text { measured? }\end{array}$ & $\begin{array}{l}\text { Test-retest for } \\
\text { knowledge } \\
\text { questions in pilot } \\
\text { study. } \\
\text { Cronbach's } \\
\text { alpha was used } \\
\text { for the entire } \\
\text { study sample for } \\
\text { the attitude } \\
\text { questions. }\end{array}$ & $\begin{array}{l}\text { Test-retest of the } \\
\text { pilot survey was } \\
\text { conducted and } \\
\text { Cronbach's alpha } \\
\text { was used to } \\
\text { establish internal } \\
\text { consistency(this was } \\
\text { measured } \\
\text { separately for each } \\
\text { component part). }\end{array}$ & $\begin{array}{l}\text { Internal } \\
\text { consistency } \\
\text { was } \\
\text { calculated } \\
\text { (unclear which } \\
\text { technique was } \\
\text { used). }\end{array}$ & $\begin{array}{l}\text { 1) Factor analysis } \\
\text { performed, and } 5 \\
\text { different factors } \\
\text { found. } 2 \text { related to } \\
\text { practice and } 3 \\
\text { related to attitudes. } \\
\text { Cronbach's alpha } \\
\text { used to demonstrate } \\
\text { internal consistency } \\
\text { within these } 5 \text { factors. } \\
\text { 2) Test-retest reliability } \\
\text { for a subsample (53) } \\
\text { and correlation } \\
\text { coefficient calculated } \\
\text { using Pearson's R. }\end{array}$ & $\begin{array}{l}\text { Internal } \\
\text { consistency } \\
\text { calculated } \\
\text { using } \\
\text { Cronbach's } \\
\text { Alpha for } \\
\text { knowledge } \\
\text { and attitude } \\
\text { sections. }\end{array}$ & $\begin{array}{l}\text { Not } \\
\text { measured. }\end{array}$ & $\begin{array}{l}\text { Internal } \\
\text { consistency } \\
\text { calculated } \\
\text { using } \\
\text { Cronbach's } \\
\text { Alpha. }\end{array}$ \\
\hline
\end{tabular}


Table 3 Quality assessment of methodology of articles included in the review

\begin{tabular}{|l|l|l|l|l|l|l|l|l|l|l}
\hline $\begin{array}{l}\text { Downe- } \\
\text { Wambol } \\
d t\end{array}$ & $\begin{array}{l}\text { Lipson } \\
\text { (2004) }\end{array}$ & $\begin{array}{l}\text { Jezewski } \\
\text { (2005) }\end{array}$ & $\begin{array}{l}\text { Scherer } \\
\text { (2006) }\end{array}$ & $\begin{array}{l}\text { Duke } \\
\text { (2007) }\end{array}$ & $\begin{array}{l}\text { Jezewski } \\
\text { (2007) }\end{array}$ & $\begin{array}{l}\text { Putman- } \\
\text { Casdorph } \\
\text { (2009) }\end{array}$ & $\begin{array}{l}\text { Zhou } \\
\text { (2012) }\end{array}$ & $\begin{array}{l}\text { Snyder } \\
\text { (2013) }\end{array}$ \\
\hline
\end{tabular}

\section{and Abstract}

\begin{tabular}{|l|l|l|l|l|l|l|l|l|l|l|}
\hline $\begin{array}{l}\text { Is the design of } \\
\text { the study design } \\
\text { reported in the } \\
\text { title and/or } \\
\text { abstract? }\end{array}$ & $\begin{array}{l}\text { Either } \\
\text { title or } \\
\text { abstract }\end{array}$ & $\begin{array}{l}\text { Either title } \\
\text { or abstract }\end{array}$ & $\begin{array}{l}\text { Either title } \\
\text { or } \\
\text { abstract }\end{array}$ & $\begin{array}{l}\text { Either title } \\
\text { or } \\
\text { abstract }\end{array}$ & $\begin{array}{l}\text { Either title } \\
\text { or abstract }\end{array}$ & $\begin{array}{l}\text { Either title } \\
\text { or } \\
\text { abstract }\end{array}$ & $\begin{array}{l}\text { Either title } \\
\text { or } \\
\text { abstract }\end{array}$ & $\begin{array}{l}\text { Either title } \\
\text { or } \\
\text { abstract }\end{array}$ & $\begin{array}{l}\text { Either title or } \\
\text { abstract }\end{array}$ & $\begin{array}{l}\text { Both title } \\
\text { and } \\
\text { abstract }\end{array}$ \\
\hline
\end{tabular}

\section{Introduction}

\begin{tabular}{|l|l|l|l|l|l|l|l|l|l|}
\hline $\begin{array}{l}\text { Is there an } \\
\text { explanation of } \\
\text { why the research } \\
\text { is necessary, } \\
\text { placing the study } \\
\text { in context of } \\
\text { previous work in } \\
\text { relevant fields? }\end{array}$ & Yes & Yes & Yes & Yes & Yes & Yes & Yes & Yes & Yes \\
\hline $\begin{array}{l}\text { Is the purpose or } \\
\text { aim of the paper } \\
\text { explained? }\end{array}$ & Yes & Yes & Yes & Yes & Yes & Yes & Yes & Yes & Yes \\
\hline
\end{tabular}

Methods

\section{Research Tool}

\begin{tabular}{|c|c|c|c|c|c|c|c|c|c|c|c|}
\hline $\begin{array}{l}\text { Is the } \\
\text { questionnaire } \\
\text { described? }\end{array}$ & $\begin{array}{l}\text { Question } \\
\text { s not } \\
\text { provided }\end{array}$ & $\begin{array}{l}\text { Core } \\
\text { questions } \\
\text { provided }\end{array}$ & $\begin{array}{l}\text { Core } \\
\text { questions } \\
\text { provided }\end{array}$ & $\begin{array}{l}\text { Core } \\
\text { questions } \\
\text { provided }\end{array}$ & $\begin{array}{l}\text { Core } \\
\text { questions } \\
\text { provided }\end{array}$ & $\begin{array}{l}\text { Core } \\
\text { questions } \\
\text { provided }\end{array}$ & $\begin{array}{l}\text { Core } \\
\text { questions } \\
\text { provided }\end{array}$ & $\begin{array}{l}\text { Core } \\
\text { questions } \\
\text { provided }\end{array}$ & $\begin{array}{l}\text { Questionnai } \\
\text { re provided }\end{array}$ & $\begin{array}{l}\text { Questionnai } \\
\text { re provided }\end{array}$ & $\begin{array}{l}\text { Questionnai } \\
\text { re provided }\end{array}$ \\
\hline
\end{tabular}




\begin{tabular}{|c|c|c|c|c|c|c|c|c|c|c|c|}
\hline $\begin{array}{l}\text { If existing tool - } \\
\text { Are its } \\
\text { psychometric } \\
\text { properties } \\
\text { presented? }\end{array}$ & $\mathrm{N} / \mathrm{A}$ & Yes & N/A & Yes & N/A & Yes & Yes & N/A & N/A & $\mathrm{N} / \mathrm{A}$ & N/A \\
\hline $\begin{array}{l}\text { If existing tool - } \\
\text { Are references to } \\
\text { the original work } \\
\text { provided? }\end{array}$ & $\mathrm{N} / \mathrm{A}$ & Yes & $\mathrm{N} / \mathrm{A}$ & Yes & N/A & Yes & Yes & $\mathrm{N} / \mathrm{A}$ & N/A & $\mathrm{N} / \mathrm{A}$ & N/A \\
\hline $\begin{array}{l}\text { New tool - Are the } \\
\text { procedures used } \\
\text { to develop and } \\
\text { pre-test it } \\
\text { reported? }\end{array}$ & $\begin{array}{l}\text { Develop } \\
\text { only }\end{array}$ & $N / A$ & $\begin{array}{l}\text { Pre-Test } \\
\text { only }\end{array}$ & N/A & $\begin{array}{l}\text { Develop } \\
\text { only }\end{array}$ & N/A & N/A & Both & Neither & $\begin{array}{l}\text { Develop } \\
\text { only }\end{array}$ & Both \\
\hline $\begin{array}{l}\text { New tool - Have } \\
\text { its reliability and } \\
\text { validity been } \\
\text { reported? }\end{array}$ & $\begin{array}{l}\text { Validity } \\
\text { only }\end{array}$ & Both & Both & $\mathrm{N} / \mathrm{A}$ & Both & N/A & N/A & Both & $\begin{array}{l}\text { Reliability } \\
\text { only }\end{array}$ & Neither & Both \\
\hline $\begin{array}{l}\text { Is a description of } \\
\text { the scoring } \\
\text { procedures } \\
\text { provided? }\end{array}$ & Yes & $\mathrm{N} / \mathrm{A}$ & N/A & Yes & No & Yes & Yes & Yes & Yes & $\mathrm{N} / \mathrm{A}$ & Yes \\
\hline
\end{tabular}

\begin{tabular}{|c|c|c|c|c|c|c|c|c|c|c|c|}
\hline $\begin{array}{l}\text { Is there a } \\
\text { description of the } \\
\text { survey population } \\
\text { and the sample } \\
\text { frame used to } \\
\text { identify this } \\
\text { population? }\end{array}$ & Both & Both & Both & Both & Both & Both & Both & $\begin{array}{l}\text { Sample } \\
\text { frame }\end{array}$ & $\begin{array}{l}\text { Sample } \\
\text { frame }\end{array}$ & Both & Both \\
\hline $\begin{array}{l}\text { Do the authors } \\
\text { provide a } \\
\text { description of }\end{array}$ & Yes & No & No & No & No & No & No & No & No & Yes & Yes \\
\hline
\end{tabular}




\begin{tabular}{|c|c|c|c|c|c|c|c|c|c|c|c|}
\hline $\begin{array}{l}\text { how } \\
\text { representative the } \\
\text { sample is of the } \\
\text { underlying } \\
\text { population? }\end{array}$ & & & & & & & & & & & \\
\hline $\begin{array}{l}\text { Is a sample size } \\
\text { calculation or } \\
\text { rationale/justificati } \\
\text { on for the sample } \\
\text { size reported }\end{array}$ & Yes & Yes & Yes & Yes & No & Yes & No & No & No & Yes & No \\
\hline
\end{tabular}

\section{Survey}

Administration

\begin{tabular}{|c|c|c|c|c|c|c|c|c|c|c|c|}
\hline $\begin{array}{l}\text { Is the mode of } \\
\text { administration } \\
\text { reported? }\end{array}$ & Mail & Mail & Mail & Mail & $\begin{array}{l}\text { In person - } \\
\text { self } \\
\text { administer } \\
\text { ed }\end{array}$ & Mail & Mail & Online & Mail & Online & Mail \\
\hline $\begin{array}{l}\text { Do the authors } \\
\text { provide } \\
\text { information on } \\
\text { the type of } \\
\text { contact and how } \\
\text { many attempts } \\
\text { were made to } \\
\text { contact subjects } \\
\text { (i.e., } \\
\text { prenotification by } \\
\text { letter or } \\
\text { telephone, } \\
\text { reminder } \\
\text { postcard, } \\
\text { duplicate } \\
\text { questionnaire with } \\
\text { reminder etc.)? }\end{array}$ & $\begin{array}{l}\text { Type } \\
\text { and } \\
\text { number }\end{array}$ & $\begin{array}{l}\text { Type and } \\
\text { number }\end{array}$ & $\begin{array}{l}\text { Type and } \\
\text { number }\end{array}$ & $\begin{array}{l}\text { Type and } \\
\text { number }\end{array}$ & Type only & Type only & Type only & $\begin{array}{l}\text { Type and } \\
\text { number }\end{array}$ & $\begin{array}{l}\text { Type and } \\
\text { number }\end{array}$ & Type only & $\begin{array}{l}\text { Type and } \\
\text { number }\end{array}$ \\
\hline
\end{tabular}




\begin{tabular}{|c|c|c|c|c|c|c|c|c|c|c|c|}
\hline $\begin{array}{l}\text { Do the authors } \\
\text { report whether } \\
\text { incentives were } \\
\text { provided } \\
\text { (financial or } \\
\text { other)? }\end{array}$ & $\begin{array}{l}\text { Not } \\
\text { Reporte } \\
\text { d }\end{array}$ & $\begin{array}{l}\text { Yes. } \\
\text { Incentive } \\
\text { provided, }\end{array}$ & $\begin{array}{l}\text { Not } \\
\text { Reported }\end{array}$ & $\begin{array}{l}\text { Not } \\
\text { Reported }\end{array}$ & $\begin{array}{l}\text { Not } \\
\text { Reported }\end{array}$ & $\begin{array}{l}\text { Not } \\
\text { Reported }\end{array}$ & $\begin{array}{l}\text { Yes. } \\
\text { Incentive } \\
\text { provided }\end{array}$ & $\begin{array}{l}\text { Yes. } \\
\text { Incentive } \\
\text { provided }\end{array}$ & $\begin{array}{l}\text { Not } \\
\text { Reported }\end{array}$ & $\begin{array}{l}\text { Not } \\
\text { Reported }\end{array}$ & $\begin{array}{l}\text { Not } \\
\text { Reported }\end{array}$ \\
\hline $\begin{array}{l}\text { If reported, what } \\
\text { incentive was } \\
\text { provided. }\end{array}$ & & 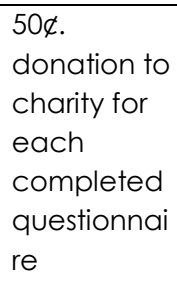 & & & & & $\begin{array}{l}\$ 10 \text { gift } \\
\text { card }\end{array}$ & $\begin{array}{l}\$ 25 \text { gift } \\
\text { certificat } \\
e\end{array}$ & & & \\
\hline $\begin{array}{l}\text { Is there a } \\
\text { description of } \\
\text { who approached } \\
\text { potential } \\
\text { participants (e.g., } \\
\text { identification of } \\
\text { who signed the } \\
\text { covering letter)? }\end{array}$ & No & No & No & No & No & No & No & No & No & No & Yes \\
\hline
\end{tabular}

\section{Analysis}

\begin{tabular}{|c|c|c|c|c|c|c|c|c|c|c|c|}
\hline $\begin{array}{l}\text { Is the method of } \\
\text { data analysis } \\
\text { reported? }\end{array}$ & $\begin{array}{l}\text { Adequat } \\
\mathrm{e}\end{array}$ & Adequate & $\begin{array}{l}\text { Adequat } \\
\mathrm{e}\end{array}$ & $\begin{array}{l}\text { Adequat } \\
\mathrm{e}\end{array}$ & Adequate & $\begin{array}{l}\text { Adequat } \\
\mathrm{e}\end{array}$ & $\begin{array}{l}\text { Adequat } \\
\mathrm{e}\end{array}$ & $\begin{array}{l}\text { Adequat } \\
\mathrm{e}\end{array}$ & Inadequate & Adequate & Adequate \\
\hline $\begin{array}{l}\text { Do the authors } \\
\text { provide methods } \\
\text { for analysis of } \\
\text { nonresponse } \\
\text { error? }\end{array}$ & No & No & No & No & No & No & No & No & No & No & No \\
\hline $\begin{array}{l}\text { Is the method for } \\
\text { calculating }\end{array}$ & Yes & Yes & Yes & Yes & Yes & Yes & Yes & Yes & Yes & Yes & Yes \\
\hline
\end{tabular}




\begin{tabular}{|l|l|l|l|l|l|l|l|l|l|}
\hline $\begin{array}{l}\text { response rate } \\
\text { provided? }\end{array}$ & & & & & & & & & \\
\hline $\begin{array}{l}\text { Are definitions } \\
\text { provided for } \\
\text { complete versus } \\
\text { partial } \\
\text { completions? }\end{array}$ & No & No & Yes & Yes & No & Yes & No & No & No \\
\hline $\begin{array}{l}\text { Are the methods } \\
\text { for handling item } \\
\text { missing data } \\
\text { reported? }\end{array}$ & No & Yes & Yes & Yes & No & No & Nes & No & Yes \\
\hline
\end{tabular}

\section{Results}

\begin{tabular}{|c|c|c|c|c|c|c|c|c|c|c|c|}
\hline $\begin{array}{l}\text { Is the response } \\
\text { rate reported? }\end{array}$ & $\begin{array}{l}\text { Yes, } \\
\text { defined }\end{array}$ & $\begin{array}{l}\text { Yes, } \\
\text { defined }\end{array}$ & $\begin{array}{l}\text { Yes, } \\
\text { defined }\end{array}$ & $\begin{array}{l}\text { Yes, } \\
\text { defined }\end{array}$ & $\begin{array}{l}\text { Yes, } \\
\text { defined }\end{array}$ & $\begin{array}{l}\text { Yes, } \\
\text { defined }\end{array}$ & $\begin{array}{l}\text { Yes, not } \\
\text { defined }\end{array}$ & $\begin{array}{l}\text { Yes, } \\
\text { defined }\end{array}$ & $\begin{array}{l}\text { Yes, } \\
\text { defined }\end{array}$ & $\begin{array}{l}\text { Yes, } \\
\text { defined }\end{array}$ & $\begin{array}{l}\text { Yes, } \\
\text { defined }\end{array}$ \\
\hline $\begin{array}{l}\text { Are all } \\
\text { respondents } \\
\text { accounted for? }\end{array}$ & Yes & Yes & Yes & Yes & Yes & Yes & Yes & Yes & Yes & Yes & Yes \\
\hline $\begin{array}{l}\text { Is information } \\
\text { given on how } \\
\text { non-respondents } \\
\text { differ from } \\
\text { respondents? }\end{array}$ & $\begin{array}{l}\text { Issue } \\
\text { addresse } \\
\text { d }\end{array}$ & $\begin{array}{l}\text { No } \\
\text { information }\end{array}$ & $\begin{array}{l}\text { No } \\
\text { informati } \\
\text { on }\end{array}$ & $\begin{array}{l}\text { No } \\
\text { informati } \\
\text { on }\end{array}$ & $\begin{array}{l}\text { No } \\
\text { information }\end{array}$ & $\begin{array}{l}\text { No } \\
\text { informati } \\
\text { on }\end{array}$ & $\begin{array}{l}\text { No } \\
\text { informati } \\
\text { on }\end{array}$ & $\begin{array}{l}\text { No } \\
\text { informati } \\
\text { on }\end{array}$ & $\begin{array}{l}\text { Issue } \\
\text { addressed }\end{array}$ & $\begin{array}{l}\text { Issue } \\
\text { addressed }\end{array}$ & $\begin{array}{l}\text { No } \\
\text { information }\end{array}$ \\
\hline $\begin{array}{l}\text { Are the results } \\
\text { clearly } \\
\text { presented? }\end{array}$ & $\begin{array}{l}\text { Yes, } \\
\text { partial }\end{array}$ & Yes, partial & $\begin{array}{l}\text { Yes, } \\
\text { partial }\end{array}$ & $\begin{array}{l}\text { Yes, } \\
\text { complete }\end{array}$ & Yes, partial & $\begin{array}{l}\text { Yes, } \\
\text { complete }\end{array}$ & $\begin{array}{l}\text { Yes, } \\
\text { partial }\end{array}$ & $\begin{array}{l}\text { Yes, } \\
\text { complete }\end{array}$ & $\begin{array}{l}\text { Yes, } \\
\text { complete }\end{array}$ & $\begin{array}{l}\text { Yes, } \\
\text { complete }\end{array}$ & $\begin{array}{l}\text { Yes, } \\
\text { complete }\end{array}$ \\
\hline $\begin{array}{l}\text { Do the results } \\
\text { address the } \\
\text { objective }(s) \text { ? }\end{array}$ & No & Yes & Yes & Yes & Yes & Yes & Yes & Yes & Yes & Yes & Yes \\
\hline
\end{tabular}

Discussion 


\begin{tabular}{|c|c|c|c|c|c|c|c|c|c|c|c|}
\hline $\begin{array}{l}\text { Are the results } \\
\text { summarized with } \\
\text { reference to the } \\
\text { study objectives? }\end{array}$ & Yes & Yes & Yes & Yes & Yes & Yes & Yes & Yes & Yes & Yes & Yes \\
\hline $\begin{array}{l}\text { Are the strengths } \\
\text { of the study } \\
\text { stated? }\end{array}$ & Yes & Yes & Yes & No & No & No & No & Yes & No & No & No \\
\hline $\begin{array}{l}\text { Are the limitations } \\
\text { of the study } \\
\text { (taking into } \\
\text { account potential } \\
\text { sources of bias or } \\
\text { imprecision) } \\
\text { stated? }\end{array}$ & Yes & Yes & Yes & Yes & Yes & Yes & Yes & Yes & Yes & Yes & Yes \\
\hline $\begin{array}{l}\text { Is the } \\
\text { generisability of } \\
\text { the study results } \\
\text { discussed? }\end{array}$ & No & Yes & Yes & Yes & No & Yes & Yes & Yes & Yes & Yes & Yes \\
\hline
\end{tabular}

\section{Ethical Quality}

Indicators

\begin{tabular}{|l|l|l|l|l|l|l|l|l|l|l|}
\hline $\begin{array}{l}\text { Study funding } \\
\text { reported? }\end{array}$ & No & No & No & No & No & Yes & No & No & Yes \\
\hline $\begin{array}{l}\text { Research Ethics } \\
\text { Board (REB) } \\
\text { review reported? }\end{array}$ & Yes & Yes & Yes & Yes & Yes & Yes & Yes & Yes & Yes \\
\hline $\begin{array}{l}\text { Reporting of } \\
\text { subject consent } \\
\text { procedures? }\end{array}$ & No & Yes & No & No & No & No & Yes & Yes & No \\
\hline
\end{tabular}

Summary Score (Good $=>75 \%$ of criteria met; Moderate $=\mathbf{5 0 - 7 5 \%}$ of criteria met; Poor $=<50 \%$ of criteria met)

\begin{tabular}{|l|l|l|l|l|l|l|l|l|l|l|l|}
\hline Percentage Score & $63 \%$ & $81 \%$ & $72 \%$ & $73 \%$ & $56 \%$ & $68 \%$ & $65 \%$ & $74 \%$ & $65 \%$ & $74 \%$ & \\
\hline
\end{tabular}




\begin{tabular}{|l|l|l|l|l|l|l|l|l|l|l|l|}
\hline Rating & $\begin{array}{l}\text { Moderat } \\
\text { e }\end{array}$ & Good & $\begin{array}{l}\text { Moderat } \\
\text { e }\end{array}$ & $\begin{array}{l}\text { Moderat } \\
\text { e }\end{array}$ & Moderate & $\begin{array}{l}\text { Moderat } \\
\text { e }\end{array}$ & $\begin{array}{l}\text { Moderat } \\
\text { e }\end{array}$ & $\begin{array}{l}\text { Moderat } \\
\text { e }\end{array}$ & Moderate & Moderate & Moderate \\
\hline
\end{tabular}

